\title{
Low hygroscopic scattering enhancement of boreal aerosol and the implications for a columnar optical closure study
}

\author{
P. Zieger ${ }^{1}$, P. P. Aalto ${ }^{2}$, V. Aaltonen ${ }^{3}$, M. Äijälä ${ }^{2}$, J. Backman ${ }^{2, a}$, J. Hong ${ }^{2}$, M. Komppula ${ }^{4}$, R. Krejci ${ }^{1,2}$, M. Laborde ${ }^{5,6}$, \\ J. Lampilahti ${ }^{2}$, G. de Leeuw ${ }^{2,3}$, A. Pfüller ${ }^{4}$, B. Rosati ${ }^{7}$, M. Tesche ${ }^{1, b}$, P. Tunved ${ }^{1}$, R. Väänänen ${ }^{2}$, and T. Petäjää \\ ${ }^{1}$ Stockholm University, Department of Environmental Science and Analytical Chemistry \& \\ Bolin Centre for Climate Research, Stockholm, Sweden \\ ${ }^{2}$ University of Helsinki, Department of Physics, Helsinki, Finland \\ ${ }^{3}$ Finnish Meteorological Institute, Climate Research Unit, Helsinki, Finland \\ ${ }^{4}$ Finnish Meteorological Institute, Atmospheric Research Centre of Eastern Finland, Kuopio, Finland \\ ${ }^{5}$ AerosolConsultingML GmbH, Lausanne, Switzerland \\ ${ }^{6}$ Ecotech Pty Ltd., Melbourne, Australia \\ ${ }^{7}$ Paul Scherrer Institute, Laboratory of Atmospheric Chemistry, Villigen, Switzerland \\ ${ }^{a}$ now at: Finnish Meteorological Institute, Atmospheric Composition Research, Helsinki, Finland \\ bnow at: University of Hertfordshire, School of Physics, Astronomy and Mathematics, \\ Herts AL10 9AB, UK
}

Correspondence to: P. Zieger (paul.zieger@aces.su.se)

Received: 20 December 2014 - Published in Atmos. Chem. Phys. Discuss.: 05 February 2015

Revised: 29 May 2015 - Accepted: 16 June 2015 - Published: 02 July 2015

\begin{abstract}
Ambient aerosol particles can take up water and thus change their optical properties depending on the hygroscopicity and the relative humidity $(\mathrm{RH})$ of the surrounding air. Knowledge of the hygroscopicity effect is of crucial importance for radiative forcing calculations and is also needed for the comparison or validation of remote sensing or model results with in situ measurements. Specifically, particle light scattering depends on RH and can be described by the scattering enhancement factor $f(\mathrm{RH})$, which is defined as the particle light scattering coefficient at defined $\mathrm{RH}$ divided by its dry value $(\mathrm{RH}<30-40 \%)$.

Here, we present results of an intensive field campaign carried out in summer 2013 at the SMEAR II station at Hyytiälä, Finland. Ground-based and airborne measurements of aerosol optical, chemical and microphysical properties were conducted. The $f(\mathrm{RH})$ measured at ground level by a humidified nephelometer is found to be generally lower (e.g. $1.63 \pm 0.22$ at $\mathrm{RH}=85 \%$ and $\lambda=525 \mathrm{~nm}$ ) than observed at other European sites. One reason is the high organic mass fraction of the aerosol encountered at Hyytiälä to which $f(\mathrm{RH})$ is clearly anti-correlated $\left(R^{2} \approx 0.8\right)$. A simplified parametrization of $f(\mathrm{RH})$ based on the measured chem-
\end{abstract}

ical mass fraction can therefore be derived for this aerosol type. A trajectory analysis revealed that elevated values of $f(\mathrm{RH})$ and the corresponding elevated inorganic mass fraction are partially caused by transported hygroscopic sea spray particles. An optical closure study shows the consistency of the ground-based in situ measurements.

Our measurements allow to determine the ambient particle light extinction coefficient using the measured $f(\mathrm{RH})$. By combining the ground-based measurements with intensive aircraft measurements of the particle number size distribution and ambient RH, columnar values of the particle extinction coefficient are determined and compared to columnar measurements of a co-located AERONET sun photometer. The water uptake is found to be of minor importance for the column-averaged properties due to the low particle hygroscopicity and the low RH during the daytime of the summer months. The in situ derived aerosol optical depths (AOD) clearly correlate with directly measured values of the sun photometer but are substantially lower compared to the directly measured values (factor of $\sim 2-3$ ). The comparison degrades for longer wavelengths. The disagreement between in situ derived and directly measured AOD is hypothesized 
to originate from losses of coarse and fine mode particles through dry deposition within the canopy and losses in the in situ sampling lines. In addition, elevated aerosol layers (above $3 \mathrm{~km}$ ) from long-range transport were observed using an aerosol lidar at Kuopio, Finland, about $200 \mathrm{~km}$ east-northeast of Hyytiälä. These elevated layers further explain parts of the disagreement.

\section{Introduction}

The uptake of water by atmospheric aerosol particles depends on the particle's hygroscopicity and the ambient relative humidity (RH). The exchange of water vapour with the environment causes a change in size and refractive index (RI) of aerosol particles and therefore directly influences its optical properties. Especially the particle light scattering coefficient $\sigma_{\mathrm{sp}}$ is strongly dependent on $\mathrm{RH}$. The main quantity describing this effect is called the scattering enhancement factor $f(\mathrm{RH}, \lambda)$, which is defined as $\sigma_{\mathrm{sp}}(\lambda)$ at elevated $\mathrm{RH}$ divided by its dry value

$f(\mathrm{RH}, \lambda)=\frac{\sigma_{\mathrm{sp}}(\mathrm{RH}, \lambda)}{\sigma_{\mathrm{sp}}\left(\mathrm{RH}_{\mathrm{dry}}, \lambda\right)}$,

where $\lambda$ denotes the wavelength, which will be omitted from now on for simplicity. Nevertheless, one should keep in mind that all optical properties are dependent on $\lambda$.

Long-term in situ measurements of aerosol scattering coefficients are usually performed at dry conditions (WMO/GAW, 2003, for example, recommends a RH below $30-40 \%$ ), but these in situ measured values differ from the ambient- and thus climate-relevant ones. Knowledge of this $\mathrm{RH}$ effect is therefore important for the calculation of the direct aerosol radiative forcing (see e.g. Pilinis et al., 1995). In addition, the RH effect is also important for the validation of model parametrizations (Zieger et al., 2013) or for the comparison and validation of remote sensing to in situ measurements (e.g. Tesche et al., 2014; Zieger et al., 2011, 2012; Esteve et al., 2012; Morgan et al., 2010; Voss et al., 2001; Ferrare et al., 1998).

The magnitude of $f(\mathrm{RH})$ mainly depends on the aerosol chemical composition and size. Several studies have experimentally determined $f(\mathrm{RH})$ for different ambient aerosol types using humidified nephelometer systems (see e.g. FierzSchmidhauser et al., 2010a; Covert et al., 1972; Pilat and Charlson, 1966, and Sect. 3.1). Arctic and marine aerosols usually show the greatest values of $f(\mathrm{RH})$ which decrease with increasing anthropogenic influence (e.g. $f(85 \%$, $550 \mathrm{~nm}) \approx 2-3.5$; Titos et al., 2014a; Zieger et al., 2010; Fierz-Schmidhauser et al., 2010c; Wang et al., 2007; Carrico et al., 1998, 2000, 2003; Gasso et al., 2000; McInnes et al., 1998). Continental aerosols (e.g. $f(85 \%, 550 \mathrm{~nm}) \approx 1.8$ 2.8; Zieger et al., 2012, 2014; Fierz-Schmidhauser et al., 2010b; Koloutsou-Vakakis et al., 2001; Sheridan et al.,
$2001)$ and urban aerosols (e.g. $f(85 \%, 550 \mathrm{~nm}) \approx 1.3-1.6$; Titos et al., 2014b; Zieger et al., 2011; Yan et al., 2009; McInnes et al., 1998; Fitzgerald et al., 1982) are observed with intermediate values. Low values are usually seen for biomass burning aerosol (e.g. $f(80 \%, 550 \mathrm{~nm}) \approx 1.01-1.51$; Kotchenruther and Hobbs, 1998) or for highly polluted air masses (e.g. $f(80 \%, 550 \mathrm{~nm}) \approx 1.07-2.35$; Pan et al., 2009). Low values have also been reported for mineral dust which can be transported over long distances e.g. from the Sahara to the European continent (e.g. $f(85 \%, 550 \mathrm{~nm}) \approx 1.2-1.7$; Titos et al., 2014b; Zieger et al., 2012; Fierz-Schmidhauser et al., 2010b). In boreal environments, the aerosol particles are typically less hygroscopic (Swietlicki et al., 2008; Ehn et al., 2007; Petäjä et al., 2005; Hämeri et al., 2001) due to a large contribution of organics (Allan et al., 2006). So far, the $f(\mathrm{RH})$ of particles representative for boreal regions has not been characterized in great detail. This is the topic of the current study where $f(\mathrm{RH})$ is analyzed combining highly time resolved and detailed aerosol micro-physical and chemical measurements. The results are further used to extrapolate the ground-based in situ measurements, which include the $\mathrm{RH}$ effect on the particle light scattering, to the atmospheric column using airborne measurements of the particle number concentration and size.

The motivation for this study is based on two research questions:

1. What is the magnitude of the scattering enhancement factor $f(\mathrm{RH})$ in the boreal forest region of northern Europe?

2. Can an optical closure between ground-based in situ and remote sensing aerosol measurements be achieved?

\section{The field site at Hyytiälä}

A measurement campaign with ground-based and airborne measurements was carried out from May to August 2013 at the SMEAR II station at Hyytiälä, Finland, as part of the EU-FP7 project PEGASOS (Pan-European Gas-Aerosolsclimate interaction Study). The station is located in southern Finland $\left(61.85^{\circ} \mathrm{N}, 24.28^{\circ} \mathrm{E}, 180 \mathrm{~m}\right.$ a.s.l.) and is surrounded by a dense coniferous forest and several lakes. The largest city close by is Tampere ( $60 \mathrm{~km}$ south-west of the site). More details on the long-term in situ measurements and the site can be found in Vesala et al. (1998) and Hari and Kulmala (2005). Most of the instrumentation used for monitoring purposes of aerosol properties was located in separate cottages within the forest, while the instruments installed specifically for the PEGASOS campaign were located in separate measurement containers and had their own inlets (see Sect. 3). The containers were located on an open parking lot $30 \mathrm{~m}$ away from the main cottage, where most of the aerosol monitoring instruments were located. The inlets of the measurement containers were $\sim 4 \mathrm{~m}$ above ground, while the inlets of the aerosol 
cottage were $\sim 5 \mathrm{~m}$ above ground and $\sim 10-15 \mathrm{~m}$ below the top of the canopy.

In May and June 2013, intensive airborne measurements were conducted around Hyytiälä. This included sampling from an airship (Zeppelin) and more frequently from a Cessna (see Sect. 3.6), the data of which will be used in this study. The ground-based in situ measurements continued until the beginning of August 2013.

\section{Instrumental}

\subsection{Particle hygroscopicity measurements}

A humidified nephelometer (WetNeph) was deployed to measure the effect of water uptake on the particle light scattering coefficient. The instrument is described in detail by Fierz-Schmidhauser et al. (2010a); therefore only a brief description will be given here. The WetNeph consists of a specifically designed single-stream humidification system, where the aerosol first enters a humidifier (at a flow rate of $9.5 \mathrm{~L} \mathrm{~min}^{-1}$ ) and then a drier before the particle light-scattering coefficients are measured by an integrating nephelometer at three wavelengths $(\lambda=450,525$, $635 \mathrm{~nm}$ ). An LED-based nephelometer (Ecotech Pty Ltd., Aurora 3000) was used, which is less affected by the heat of the lamp that could influence the RH inside the nephelometer. The WetNeph was set to the humidograph mode, where the $\mathrm{RH}$ inside the nephelometer is periodically cycled between 35 and 40 and $90-95 \%$ (slightly depending on the temperature inside the measurement container). One full humidograph cycle (hydration and dehydration) took $3 \mathrm{~h}$. This set-up allows to measure the upper and lower branch of the aerosol hysteresis curve separately. Dry scattering coefficients were measured in parallel with a second (reference) nephelometer of the same type as the WetNeph with an average RH inside the nephelometer cell of $27.5 \pm 5.5 \%$ (mean \pm standard deviation; SD). From these data, Eq. (1) is then used to calculate $f(\mathrm{RH})$ for each nephelometer wavelength.

All scattering coefficients were corrected for the truncation error and non-idealities of the light source by the scheme described in Müller et al. (2011). First, the nephelometers were calibrated using particle-free air and $\mathrm{CO}_{2}$ as a span gas. Then both nephelometers were run in parallel, measuring the same aerosol at the same RH, to determine the relative differences between the two instruments. Relative differences between 5 and $12 \%$ were found for the three wavelengths, which was accounted for when calculating the intensive parameter $f(\mathrm{RH})$. In addition, measured humidograms of polydisperse ammonium sulphate particles measured at the site were compared to model predictions using the size distributions measured by a differential mobility particle sizer (DMPS) system (with a diameter range of 6 to $600 \mathrm{~nm}$, see below), theoretical growth factors of ammonium sulphate and Mie theory (Fierz-Schmidhauser et al., 2010a).
Good agreement was found; however, the modelled values of $f(\mathrm{RH})$ were $5-10 \%$ above the measured values, which can be attributed firstly to the presence of few large particles that were not included in the model calculations (due to the size cut of the DMPS) and would lead to a lower predicted $f(\mathrm{RH})$ (Zieger et al., 2013), secondly to the RH sensor's uncertainty (1-2\% absolute difference, Rotronic HygroClip) and finally to the losses in the WetNeph system itself (between 2.5 and $5 \%$, Fierz-Schmidhauser et al., 2010a). The relative measurement uncertainty of $f(\mathrm{RH})$ as an upper and conservative estimate is $20 \%$ at $\mathrm{RH}=85 \%$ (FierzSchmidhauser et al., 2010a; Zieger et al., 2013). The WetNeph showed a good agreement to a novel commercially available humidified nephelometer system (aerosol conditioning system (ACS1000) by Ecotech Pty Ltd.) for certain periods of the campaign. At $85 \% \mathrm{RH}$ the median $f(\mathrm{RH})$ agreed within $6 \%$ for $525 \mathrm{~nm}$ (M. Laborde, personal communication, April 2015).

The humidograms of $f(\mathrm{RH})$ can be described by an empirical two-parameter fit (e.g. Clarke et al., 2002; Carrico et al., 2003):

$f(\mathrm{RH})=a(1-\mathrm{RH})^{-\gamma}$.

The parameter $a$ in Eq. (2) is the intercept at $\mathrm{RH}=0 \%$ while $\gamma$ describes the magnitude of the measured $f(\mathrm{RH})$. In previous work (Zieger et al., 2011, 2014), the upper and lower branches were fitted separately to the humidograms to investigate the existence of aerosol deliquescence (sudden transition from the solid to the liquid state of the particles; usually caused by pure inorganic salts). However, no deliquescence was observed at Hyytiälä due to the dominance of organic substances.

While $f(\mathrm{RH})$ represents the hygroscopic growth as an optical measure, one can also describe the hygroscopic growth by the change in particle diameter. The hygroscopic growth factor $g(\mathrm{RH})$ is defined as the ratio of the particle diameter at elevated RH to its dry diameter

$g(\mathrm{RH})=\frac{D_{\mathrm{p}, \mathrm{wet}}(\mathrm{RH})}{D_{\mathrm{p}, \mathrm{dry}}}$.

$g(\mathrm{RH})$ was determined using a hygroscopicity tandem differential mobility analyzer (H-TDMA), which is part of a volatile hygroscopicity tandem differential mobility analyzer system. Detailed information on the system can be found in Hong et al. (2014). Four dry mobility diameters were selected $\left(D_{\mathrm{p}, \text { dry }}=30,60,100,145 \mathrm{~nm}\right)$ and their humidified size distribution was measured at $\mathrm{RH}=90 \pm 2 \%$ by a second differential mobility analyzer (DMA) and condensation particle counter (CPC, TSI Inc., Model 3772) system. The H-TDMA was calibrated with ammonium sulphate particles at $90 \% \mathrm{RH}$ before the ambient sampling. 


\subsection{Particle absorption measurements}

A filter-based absorption photometer (aethalometer, Model AE-31, Maggee Scientific) was used to measure equivalent black carbon (EBC) mass concentrations (Weingartner et al., 2003; Petzold et al., 2013). The aethalometer is a multiwavelength instrument that measures the particle light absorption coefficient $\sigma_{\text {ap }}$ at seven wavelengths by recording the attenuation of light through a filter where particles deposit. The instrument then converts the subsequent increase in attenuation to EBC concentrations using a mass absorption cross section of $14625 \mathrm{~nm} \mathrm{~m}^{2} \mathrm{~g}^{-1} \lambda^{-1}$. The instrument was measuring behind a Digitel $\mathrm{PM}_{10}$ ambient humidity inlet with a flow rate of $30 \mathrm{~L} \mathrm{~min}^{-1}$. A site-specific correction factor of $C=3.35$ to correct for multiple scattering within the filter was applied (Weingartner et al., 2003). A more detailed description of the aethalometer measurements at the site is given by Virkkula et al. (2011).

\subsection{Particle size distribution measurements}

The particle number size distribution was determined at ground level using a DMPS for the fine mode (electrical mobility diameter, $D_{\mathrm{p}}<1 \mu \mathrm{m}$ ) and an aerodynamic particle sizer (APS) for the coarse mode (aerodynamic particle diameter $\left.D_{\mathrm{p}}>1 \mu \mathrm{m}\right)$. The Hyytiälä-DMPS is a twin DMPS setup. DMPS1 has a $10.9 \mathrm{~cm}$ long Vienna-type DMA followed by a CPC (TSI Inc., Model 3025). The measurement range is 3 to $40 \mathrm{~nm}$ (electrical mobility diameter) with a sheath flow rate of $20 \mathrm{~L} \mathrm{~min}^{-1}$ and an aerosol flow rate of $4 \mathrm{~L} \mathrm{~min}^{-1}$. DMPS2 has a $28 \mathrm{~cm}$ long Vienna-type DMA, followed by a CPC (TSI Inc., Model 3772). The measurement range of DMPS2 is between 20 and $1000 \mathrm{~nm}$ with a sheath air of $5 \mathrm{~L} \mathrm{~min}^{-1}$ and an aerosol flow rate of $1 \mathrm{~L} \mathrm{~min}^{-1}$. The sheath flows of the twin DMPS are dried to $\mathrm{RH}<40 \%$, and continuously controlled with regulating valves and inline flow metres. The aerosol flow is brought to charge balance using a ${ }^{14} \mathrm{C}$ radioactive source and the flows are monitored using pressure drop flow metres. One measurement cycle takes about $10 \mathrm{~min}$. The Hyytiälä-DMPS is regularly calibrated and checked with standard polystyrene latex spheres particles, higher precision flow metres and has also been successfully intercompared to the ACTRIS moving standard in 2009 (Wiedensohler et al., 2012). In addition to the twin DMPS, the APS (TSI Inc., Model 3321) measured the size distribution in the aerodynamic diameter range between $520 \mathrm{~nm}$ and $20 \mu \mathrm{m}$. The aerosol is aspirated through a straight sampling line (tube diameter $16 \mathrm{~mm}$, length $4 \mathrm{~m}$ ) to the instrument to avoid particle losses. The inlet is at a height of $6 \mathrm{~m}$ above the ground and consists of a total suspended particle inlet (Digitel Inc.). The inlet is heated to $40^{\circ} \mathrm{C}$ to prevent condensation and to ensure that fog droplets are evaporated and the $\mathrm{RH}$ is below $40 \%$.

\subsection{Particle chemical composition measurements}

The aerosol chemical composition was measured by an aerosol chemical speciation monitor (ACSM, Aerodyne Research Ltd.) which is permanently deployed at Hyytiälä since March 2012. The instrument is a lighter version of the Aerodyne aerosol mass spectrometer (Canagaratna et al., 2007) developed for monitoring purposes. The ACSM inlet line had a $\mathrm{PM}_{2.5}$ cyclone filter to stop dust and pollen contamination. The inlet line is dried using a Nafion dryer, reducing sample RH below $30 \%$. At the entry to the instrument itself the sample aerosol is concentrated into a beam by a standard aerosol mass spectrometer aerodynamic lens with a cut size of approximately $600 \mathrm{~nm}$. The measured mass is assigned to five main chemical species: sulphates $\left(\mathrm{SO}_{4}\right)$, nitrates $\left(\mathrm{NO}_{3}\right)$, ammonia $\left(\mathrm{NH}_{4}\right)$, chlorides $(\mathrm{Cl})$ and organics $(\mathrm{Org})$. For a more detailed description on the data processing, the reader is referred to the studies by Allan et al. $(2003,2004)$, while more technical details on the ACSM can be found in $\mathrm{Ng}$ et al. (2011).

Assuming internally and externally well-mixed aerosol, the molar concentrations of inorganic ions can be assigned to typically observed inorganic salts: ammonium sulphate $\left(\left(\mathrm{NH}_{4}\right)_{2} \mathrm{SO}_{4}\right)$, ammonium bisulphate $\left(\left(\mathrm{NH}_{4}\right) \mathrm{HSO}_{4}\right)$ and ammonium nitrate $\left(\mathrm{NH}_{4} \mathrm{NO}_{3}\right)$. Since the amount of chlorides at Hyytiälä was negligibly low, ammonium chloride $\left(\mathrm{NH}_{4} \mathrm{Cl}\right)$ was excluded from the calculations. It was assumed that ammonium ions first pair with $\mathrm{SO}_{4}$ ions to form ammonium sulphate and/or bisulphate - depending on the molar ratio of $\mathrm{NH}_{4}$ to $\mathrm{SO}_{4}$ - with the remaining amount of $\mathrm{NH}_{4}$ being available to form ammonium nitrate. Leftover $\mathrm{NO}_{3}$ was considered to originate from organic nitrates. The loadings of $\mathrm{NH}_{4}$ were typically too low to fully neutralize all of the observed $\mathrm{SO}_{4}$ and $\mathrm{NO}_{3}$. Occasionally, the $\mathrm{SO}_{4}$ was left unneutralized, in which case they were considered to originate from sulfuric acid $\left(\mathrm{H}_{2} \mathrm{SO}_{4}\right)$. It should be noted that the above calculations are very sensitive to the assumption of well-mixed aerosol and additionally fail to account for possible organic salts (e.g. organonitrate and organosulphate compounds). As these assumptions are extreme in an ambient aerosol situation, the estimate must be considered only a rough first approximation. However, it does provide some quantitative results which we can use to predict $f(\mathrm{RH})$, as shown in Sect. 6.2.

Submicron elemental carbon (EC) mass concentration was measured using a semi-continuous organic carbon (OC)/EC analyzer (Sunset Technologies Inc.). The instrument measures the mass concentrations of $\mathrm{OC}$ and $\mathrm{EC}$ with a time resolution of approximately $3 \mathrm{~h}$. The device utilized a two-step thermal-optical method for the determination of OC and EC. More details can be found in Peterson and Richards (2002) and Karanasiou et al. (2011).

The chemical mass fraction $F_{i}$ was determined by dividing the concentrations of the individual components derived from the ACSM and EC / OC analyses by the sum of all (excluding the OC from the EC / OC analysis, which is covered 
by the ACSM measurement). The organic mass fraction $F_{\text {org }}$ was determined by adding the EC part (which is known to have a low hygroscopicity) of the EC / OC analysis to the organic components of the ACSM. The mass fraction is representative for sub-micron particles only due to the experimental restrictions.

\subsection{Auxiliary in situ instruments}

Within the monitoring network, an integrating nephelometer (TSI Inc., Model 3563) is used to measure $\sigma_{\mathrm{sp} \text {, dry }}$ at $\lambda=450,550$ and $700 \mathrm{~nm}$. The instrument is located in the aerosol cottage behind an switching $\mathrm{PM}_{1}$ and $\mathrm{PM}_{10}$ inlet (RH inside nephelometer cell $6.5 \pm 3.5 \%$ ). Here, only the $\mathrm{PM}_{10}$ measurements of $\sigma_{\mathrm{sp} \text {, dry }}$ are used to retrieve the complex refractive index and to compare the measurements of the WetNeph reference nephelometer to it. The scattering coefficients were corrected for nonidealities of the light source and the truncation error by the correction scheme of Anderson and Ogren (1998).

Meteorological parameters like temperature, wind speed and direction or $\mathrm{RH}$ were continuously measured along a $124 \mathrm{~m}$ high tower.

\subsection{Airborne measurements}

Vertical profiles of the aerosol size distributions were measured using a Cessna $172 \mathrm{~F}$ aircraft as a platform (Schobesberger et al., 2013; Leino et al., 2014). The total particle concentration was measured using an ultrafine condensation particle counter (TSI Inc., Model 3776) with a diameter cut off size of $3 \mathrm{~nm}$. A scanning mobility particle sizer (SMPS, Wang and Flagan, 1990) with a small Hauke-type DMA and CPC (TSI Inc., TSI 3010) was used to determine the particle number size distribution (mobility diameter size range of 10-270 nm). For the SMPS the inversion by Collins et al. (2002) was used, and the calibration corrections and turbulent tube losses were taken into account. Other instruments inside the cabin included the Li-Cor 840 gas analyzer measuring $\mathrm{H}_{2} \mathrm{O}$ and $\mathrm{CO}_{2}$ concentrations and a pressure sensor. Ambient air temperature was measured using a PT100 sensor. A GPS receiver recorded the flight path. The sample air inlet was a downscaled version of the inlet design used with University of Hawaii's DC-8 (McNaughton et al., 2007). It was situated under the right wing out from the propeller flow. The sample air was led inside the aircraft via a stainless steel tube of length $4.2 \mathrm{~m}$ and diameter of $22 \mathrm{~mm}$. The flow rate of the inlet tube was between 45 and $50 \mathrm{~L} \mathrm{~min}^{-1}$.

The flights were conducted with a slow airspeed of $\approx 130 \mathrm{~km} \mathrm{~h}^{-1}$. The ascend or descent rate was around $2.5 \mathrm{~m} \mathrm{~s}^{-1}$. Most of the research flights (23/30) were conducted above the area surrounding the SMEAR II station at Hyytiälä. The other flights were performed around Jämijärvi airport located $80 \mathrm{~km}$ west of Hyytiälä. The flight profiles usually contained several flight paths of around $30 \mathrm{~km}$ with constant altitudes and additionally a climb up to $3.2 \mathrm{~km}$. The direction of the flight paths was chosen to be perpendicular to the wind direction at ground. The measurements are described in more detail by Väänänen et al. (2015).

\subsection{Columnar and vertical measurements of aerosol optical properties}

Columnar aerosol optical properties were measured using a sun photometer (SPM, CIMEL CE-318) which has been operated at Hyytiälä since February 2008 (Aaltonen et al., 2012). The instrument was installed on a $18 \mathrm{~m}$ high tower above the canopy of the forest surrounding the station and is part of the AERONET network (Holben et al., 1998). It measures direct sun irradiance to obtain the aerosol optical depth (AOD) at different wavelengths $(\lambda=340,380,440$, $500,675,870,1020$ and $1640 \mathrm{~nm}$ ) and the Ångström exponent (see Eq. 6 below). The absolute uncertainty of the AOD for this instrument type was estimated by Eck et al. (1999) to be $\sim 0.01$ for the visible and near-infrared and $\sim 0.02$ for the ultraviolet region. Moreover, other optical and microphysical properties of atmospheric aerosols are routinely retrieved using an inversion scheme developed by Dubovik et al. (2006). The calibration is carried out yearly by comparison with reference instruments, after which final corrections are made and the data are available as quality-assured level 2.0 data (Holben et al., 2006). The level 2.0 data has been used in the following analysis.

In addition to the SPM measurements, data from a sevenchannel Raman lidar (PollyXT; Althausen et al., 2009; Engelmann et al., 2012) was included in the data analysis. The lidar is located in Kuopio $\left(62^{\circ} 44^{\prime} 17^{\prime \prime} \mathrm{N}, 27^{\circ} 32^{\prime} 33.5^{\prime \prime} \mathrm{E}\right.$, 190 ma.s.1.) which is $200 \mathrm{~km}$ east-north-east of Hyytiälä. It is operated by the Finnish Meteorological Institute within the Finnish observation network (Hirsikko et al., 2014) and is part of the European Aerosol Research lidar Network (EARLINET; Pappalardo et al., 2014). Polly ${ }^{X T}$ provides vertical profiles of particle backscatter coefficients at wavelengths of 355,532 and $1064 \mathrm{~nm}$ and the particle extinction coefficient at 355 and $532 \mathrm{~nm}$. The system also includes a depolarization $(532 \mathrm{~nm})$ and a water-vapour $(407 \mathrm{~nm})$ channel. The vertical resolution of the instrument is $30 \mathrm{~m}$.

\section{Trajectory calculations}

Air mass back trajectories were calculated hourly with the air parcel arriving at an altitude of $100 \mathrm{~m}$ above the site using the HYSPLIT model (Draxler, 2004; Draxler and Hess, 1998). The trajectories were calculated on the basis of the Global Data Assimilation System data set (GDAS, http://ready.arl. noaa.gov/archives.php). Along each trajectory, additional parameters such as mixing layer (ML) height, temperature, $\mathrm{RH}$ and column precipitation was calculated by the model. Each trajectory had a time length of 10 days. 


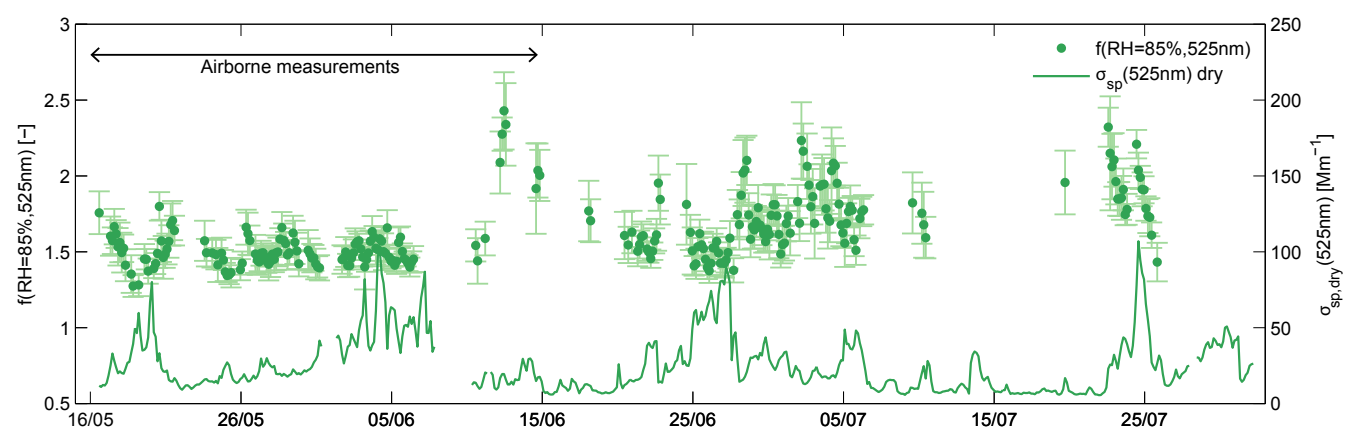

Figure 1. Time series of the scattering enhancement factor $f(\mathrm{RH})$ at $\mathrm{RH}=85 \%$ and $\lambda=525 \mathrm{~nm}$ (bullet points) and the dry particle light scattering coefficient at $\lambda=525 \mathrm{~nm}$ (solid line) measured at Hyytiälä. The error bars give the $95 \%$ confidence interval. The arrow indicates the period of airborne measurements.

(a)

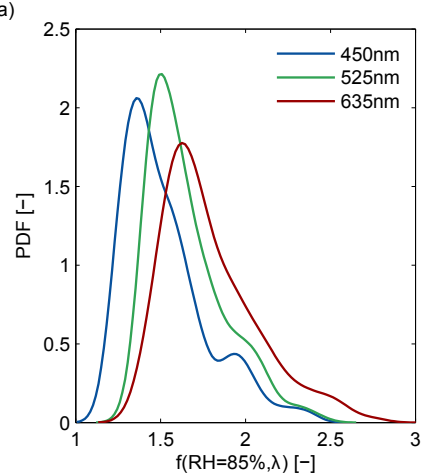

(b)

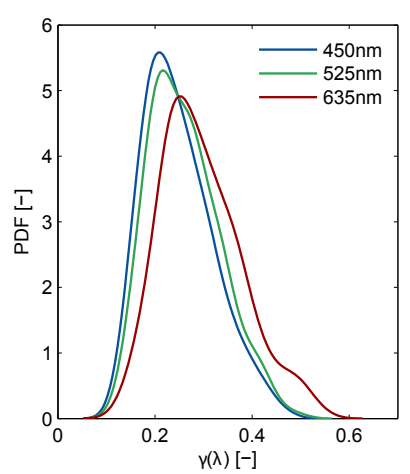

(c)

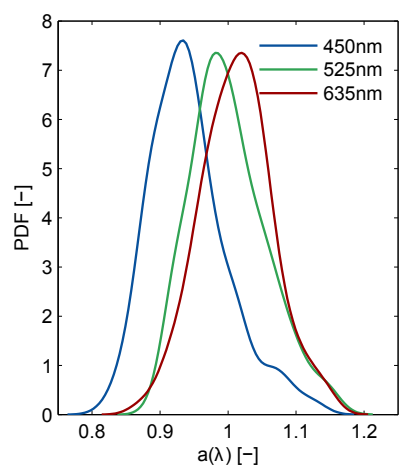

Figure 2. Probability density function (PDF) of (a) the measured $f(\mathrm{RH}=85 \%)$, (b) the fit-parameter $\gamma($ magnitude of $f(\mathrm{RH}))$ and $(\mathbf{c})$ the fit-parameter $a$ (intercept). The different lines show the result for the three nephelometer wavelengths.

The surface residence time of an air parcel was then calculated by adding the travel time of each trajectory for the entire measurement period on a $1^{\circ} \times 1^{\circ}$ longitudinal and latitudinal grid. Only periods when the air parcel was within the ML were considered.

To further differentiate between the continental and maritime influence the parameter $\psi$ is introduced:

$\psi=\int_{t_{\mathrm{start}}}^{t_{\mathrm{end}}}(\rho(t) \cdot \epsilon(t)) \mathrm{d} t$,

where $t_{\text {start }}$ denotes the start and $t_{\text {end }}$ the arrival time of the trajectory. The factor $\epsilon(t)$ in Eq. (4) is +1 if the air parcel traverses within the ML above land, while it is -1 when the parcel traverses within the ML above oceans. The factor $\rho(t)$ accounts for the removal of the particles with an estimated half-lifetime of one week (assuming a quadratic decrease with time). Other removal mechanisms (e.g. due to precipitation) are not taken into account. By this definition, $\psi$ has as outer boundaries -1 (air mass traversed only above oceans) and +1 (air mass traversed only above land). We are aware that this is a simplified way of classifying the air masses; however, it will be shown that $\psi$ sufficiently describes the maritime and continental influence for our purposes.

\section{Results}

Section 5.1 describes the results of in situ measurements of $f(\mathrm{RH})$. Its correlation and the proposed parametrization to the particle's chemical composition are discussed in Sect. 5.2 and 5.3. The following Sect. 5.4 explains the extrapolation of the ground-based in situ measurements to the atmospheric column and compares the result to routinely performed SPM measurements. Different hypothesis are discussed in Sect. 6 that can impact the comparison.

\subsection{Influence of water uptake on the aerosol light scattering coefficient at Hyytiälä}

The time series of $f(\mathrm{RH})$ at $\mathrm{RH}=85 \%$ was calculated by averaging the humidograms every $3 \mathrm{~h}$ (one full RH cycle) and applying Eq. (2) to the measurements. The result is shown in Fig. 1 together with the corresponding dry scattering coefficient $\sigma_{\text {sp, dry }}$ for $\lambda=525 \mathrm{~nm}$. $f(\mathrm{RH}=85 \%, 525 \mathrm{~nm})$ shows little variation throughout the summer months with 
Table 1. Mean, standard deviation (SD) and percentile values (prctl.) of the scattering enhancement factor $f(\mathrm{RH})$, the magnitude $\gamma$ and intercept $a$ of the fitted humidograms.

\begin{tabular}{lrrrrrrr}
\hline & Mean & SD & 90th prctl. & 75th prctl. & Median & 25th prctl. & 10th prctl. \\
\hline$f(85 \%, 450 \mathrm{~nm})$ & 1.53 & 0.24 & 1.90 & 1.64 & 1.47 & 1.35 & 1.26 \\
$f(85 \%, 525 \mathrm{~nm})$ & 1.63 & 0.22 & 1.95 & 1.74 & 1.57 & 1.48 & 1.42 \\
$f(85 \%, 635 \mathrm{~nm})$ & 1.79 & 0.27 & 2.17 & 1.94 & 1.71 & 1.59 & 1.51 \\
\hline$\gamma(450 \mathrm{~nm})$ & 0.24 & 0.07 & 0.34 & 0.28 & 0.22 & 0.19 & 0.16 \\
$\gamma(525 \mathrm{~nm})$ & 0.25 & 0.07 & 0.35 & 0.29 & 0.24 & 0.20 & 0.17 \\
$\gamma(635 \mathrm{~nm})$ & 0.30 & 0.08 & 0.41 & 0.35 & 0.28 & 0.23 & 0.20 \\
\hline$a(450 \mathrm{~nm})$ & 0.96 & 0.07 & 1.07 & 1.00 & 0.95 & 0.91 & 0.88 \\
$a(525 \mathrm{~nm})$ & 1.01 & 0.05 & 1.08 & 1.04 & 1.00 & 0.97 & 0.94 \\
$a(635 \mathrm{~nm})$ & 1.01 & 0.05 & 1.08 & 1.05 & 1.01 & 0.98 & 0.95 \\
\hline
\end{tabular}

Table 2. Mean, standard deviation (SD) and percentile values (prctl.) of the particle light scattering coefficient ( $\left.\sigma_{\mathrm{sp} \text {,dry }}\right)$, the particle light absorption coefficient $\left(\sigma_{\text {ap,dry }}\right)$, the single scattering albedo $\left(\omega_{0}\right)$, the Ångström scattering exponent $\left(\alpha_{\text {sp }}\right.$, determined by a fit) and the main aerosol chemical components (ACSM and EC / OC analysis). All optical properties are given at dry conditions and were calculated to the wavelength of the WetNeph nephelometer. The values are given for the time period when the WetNeph was in operation (see Fig. 1).

\begin{tabular}{|c|c|c|c|c|c|c|c|}
\hline & Mean & SD & 90th pretl. & 75th pretl. & Median & 25 th pretl. & 10th pretl \\
\hline$\sigma_{\mathrm{sp}, \text { dry }}(450 \mathrm{~nm})\left[\mathrm{Mm}^{-1}\right]$ & 42.03 & 25.42 & 79.57 & 52.91 & 34.07 & 22.84 & 18.35 \\
\hline$\sigma_{\mathrm{sp}, \text { dry }}(525 \mathrm{~nm})\left[\mathrm{Mm}^{-1}\right]$ & 32.90 & 19.75 & 61.18 & 40.84 & 26.61 & 18.15 & 14.60 \\
\hline$\sigma_{\mathrm{sp}, \mathrm{dry}}(635 \mathrm{~nm})\left[\mathrm{Mm}^{-1}\right]$ & 27.19 & 17.65 & 51.01 & 34.34 & 21.27 & 14.62 & 11.00 \\
\hline$\sigma_{\mathrm{ap}, \mathrm{dry}}(450 \mathrm{~nm})\left[\mathrm{Mm}^{-1}\right]$ & 2.11 & 1.19 & 3.45 & 2.54 & 1.90 & 1.32 & 0.92 \\
\hline$\sigma_{\mathrm{ap}, \mathrm{dry}}(525 \mathrm{~nm})\left[\mathrm{Mm}^{-1}\right]$ & 1.82 & 1.00 & 3.05 & 2.22 & 1.62 & 1.14 & 0.82 \\
\hline$\sigma_{\text {ap,dry }}(635 \mathrm{~nm})\left[\mathrm{Mm}^{-1}\right]$ & 1.51 & 0.82 & 2.63 & 1.89 & 1.35 & 0.94 & 0.66 \\
\hline$\omega_{\text {sp,dry }}(450 \mathrm{~nm})[-]$ & 0.95 & 0.02 & 0.97 & 0.96 & 0.95 & 0.93 & 0.91 \\
\hline$\omega_{\text {sp,dry }}(525 \mathrm{~nm})[-]$ & 0.94 & 0.03 & 0.97 & 0.96 & 0.94 & 0.93 & 0.91 \\
\hline$\omega_{\text {sp }, \operatorname{dry}}(635 \mathrm{~nm})[-]$ & 0.94 & 0.03 & 0.97 & 0.96 & 0.94 & 0.93 & 0.91 \\
\hline$\alpha_{\mathrm{sp}}[-]$ & 1.30 & 0.23 & 1.60 & 1.44 & 1.31 & 1.18 & 1.00 \\
\hline Organic mass conc. $\left[\mu \mathrm{gm}^{-3}\right]$ & 4.57 & 2.63 & 9.03 & 6.30 & 3.78 & 2.59 & 1.71 \\
\hline $\mathrm{NH}_{4}$ mass conc. $\left[\mu \mathrm{gm}^{-3}\right]$ & 0.37 & 0.15 & 0.57 & 0.46 & 0.36 & 0.26 & 0.20 \\
\hline $\mathrm{SO}_{4}$ mass conc. $\left[\mu \mathrm{gm}^{-3}\right]$ & 0.85 & 0.37 & 1.29 & 1.04 & 0.83 & 0.55 & 0.40 \\
\hline $\mathrm{NO}_{3}$ mass conc. $\left[\mu \mathrm{gm}^{-3}\right]$ & 0.20 & 0.11 & 0.37 & 0.26 & 0.16 & 0.12 & 0.10 \\
\hline $\mathrm{Cl}$ mass conc. $\left[\mu \mathrm{gm}^{-3}\right]$ & 0.01 & 0.01 & 0.02 & 0.01 & 0.01 & 0.00 & 0.00 \\
\hline $\mathrm{EC}$ mass conc. $\left[\mu \mathrm{gm}^{-3}\right]$ & 0.13 & 0.07 & 0.20 & 0.14 & 0.11 & 0.09 & 0.07 \\
\hline
\end{tabular}

a mean value of $1.63 \pm 0.22$. $f(\mathrm{RH}=85 \%, 525 \mathrm{~nm})$ decreases with increasing dry scattering coefficient $\sigma_{\mathrm{sp} \text {, dry }}$, indicating an increased presence of less hygroscopic particles at high $\sigma_{\mathrm{sp} \text {, dry }}$. The probability density function (PDF) of the measured $f(\mathrm{RH}=85 \%)$ for all nephelometer wavelengths and the entire campaign is shown in Fig. 2 together with the PDF of the fit parameters used in Eq. (2). A small increase of $f(\mathrm{RH}=85 \%)$ with increasing wavelength is observed, similar to observations made at Melpitz, Germany (Zieger et al., 2014). This effect can be reproduced by calculating the optical properties using Mie theory with the input of the measured size distribution and chemical composition of the particles. The fit-parameters $\gamma$ and $a$ consequently show a low variation with a mean and SD value of $0.25 \pm 0.07$ and $1.01 \pm 0.05$ respectively. The value of $a \approx 1$ indicates the absence of hysteresis effects. The mean, SD and percentile values of $f(\mathrm{RH}=85 \%)$ are given for all wavelengths in Table 1 together with the fit parameters (see Eq. 2). To bring our measurement results into a broader context, Table 2 shows the average values for the main aerosol optical parameters (all calculated to the nephelometer wavelengths) and the chemical composition measurements.

The $f(\mathrm{RH})$ observed at Hyytiälä is remarkably low compared to other sites. Figure 3 shows the PDF at $\mathrm{RH}=85 \%$ and $\lambda=550 \mathrm{~nm}$ (linearly interpolated) in comparison to other European sites where the same instrument with a 

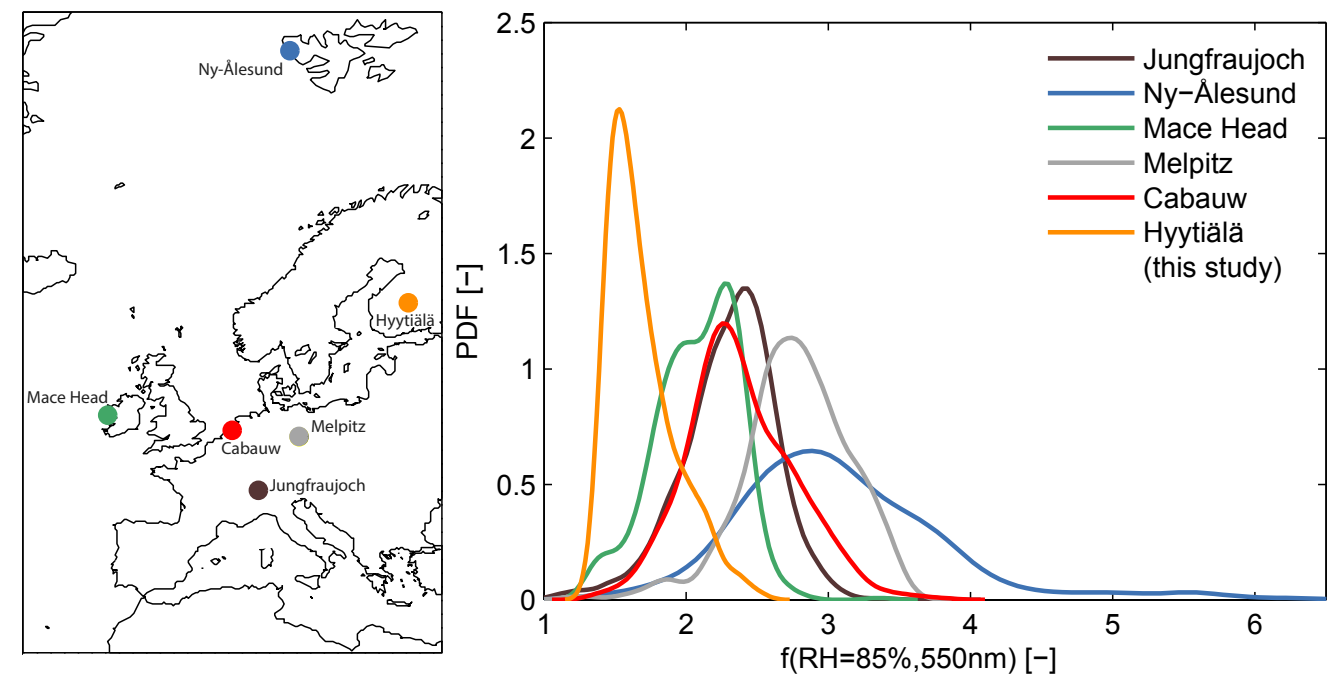

Figure 3. Probability density function (PDF) of the measured $f(\mathrm{RH}=85 \%, 550 \mathrm{~nm}$ ) at Hyytiälä (orange line) in comparison to results obtained at other European sites where the same instrument had been deployed (see legend; data taken from Zieger et al., 2013). The result for Hyytiälä was linearly interpolated to $550 \mathrm{~nm}$ wavelength. The left panel shows the location of the different sites.

different nephelometer was used (Zieger et al., 2013). High values of $f(\mathrm{RH})$ were measured for pristine maritime and Arctic aerosol found at $\mathrm{Ny}$-Ålesund, Spitsbergen (campaign mean and SD: $f(85 \%, 550 \mathrm{~nm})=3.24 \pm 0.63)$, or aerosol dominated by inorganic salts as recorded in winter 2009 at Melpitz, Germany $(f(85 \%, 550 \mathrm{~nm})=2.77 \pm 0.37)$. Intermediate values were usually measured for continental and anthropogenic influenced aerosol at Cabauw, the Netherlands $(f(85 \%, 550 \mathrm{~nm})=2.38 \pm 0.38)$, or free tropospheric aerosol at Jungfraujoch, Switzerland $(f(85 \%, 550 \mathrm{~nm})=$ $2.30 \pm 0.33)$. The $f(\mathrm{RH})$ values given above are campaign averages; however, each site had its characteristics for specific air mass types like marine aerosol, anthropogenic-influenced aerosol or desert dust. For example, Mace Head in Ireland showed distinct differences in $f(\mathrm{RH})$ depending on the wind direction; if the air had a maritime origin generally higher values were observed $(f(85 \%, 550 \mathrm{~nm})=2.28 \pm 0.19)$ in contrast to wind coming from the island or continent with influence of anthropogenic emissions $(f(85 \%, 550 \mathrm{~nm})=$ $1.80 \pm 0.26)$. A separation of different air mass types for the other sites are given in Table 2 in Zieger et al. (2013).

The trajectory analysis reveals further insights to the source of $f(\mathrm{RH})$ as shown in Fig. 4. Only concurrent times when all main in situ instruments (WetNeph, ACSM and aethalometer) were running in parallel were used. Figure $4 \mathrm{a}$ reveals that the main catchment area of the air arriving at Hyytiälä was southern Finland, Russia, the Baltic Sea, parts of Scandinavia and continental Europe as well as the Atlantic and Arctic oceans. The $f(\mathrm{RH}=85 \%, 525 \mathrm{~nm})$, the organic mass fraction and the EBC concentration were separately averaged on a $1^{\circ} \times 1^{\circ}$ grid when the air parcel of the trajectory was within the ML for each grid point. It is hereby assumed that the property did not change along the trajec- tory. It can be seen in Fig. 4b that air masses with eastern and continental origin had generally a lower $f(\mathrm{RH})$, while air masses traversing over oceans or originating from the Arctic were characterized with elevated values of $f(\mathrm{RH})$, which can be explained by the contribution of hygroscopic sea spray particles transported to Hyytiälä. However, no distinct deliquescence was observed in contrast to other sites like Melpitz (Germany), Cabauw (The Netherlands) or Ny-AAlesund (Spitzbergen), which can be explained by the high contribution of organic substances at Hyytiälä. Figure $4 c$ shows the organic mass fraction is clearly elevated for continental air masses, while it decreased for air masses having a maritime origin. Figure 4d shows the spatial distribution of the EBC as measured by the aethalometer. A strong source of EBC around St. Petersburg in Russia and generally elevated concentrations of air masses coming from the continent can be seen. No weighting or removal was considered for this analysis since mainly intensive parameters are shown. In addition, the analysis is also influenced by shadowing effects when air masses from different origin are averaged on the same grid point to one mean value. This can be avoided by using the factor $\psi$ introduced in Eq. (4), which reveals the potential maritime and continental influence. Figure 5 shows the average values of $f(\mathrm{RH}=85 \%, 525 \mathrm{~nm})$, the EBC concentration and the organic mass fraction vs. $\psi$. It can be seen that the scattering enhancement is generally higher for maritime air masses, while it clearly decreases with increasing continental influence. As an opposite trend, the organic mass fraction steadily increases with more continental influence. The EBC values show no significant trend compared to $f(\mathrm{RH})$ or the organic mass fraction.

The measured scattering enhancement factors have been compared to further in situ measured aerosol and 


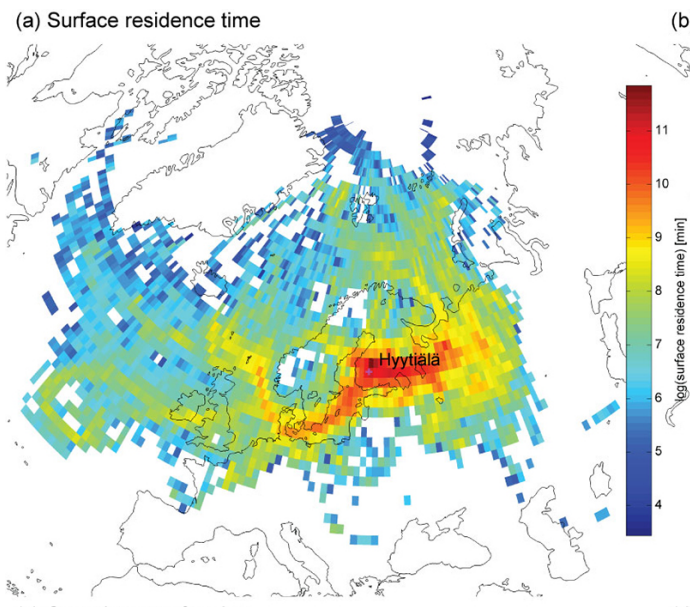

(b) Scattering enhancement factor

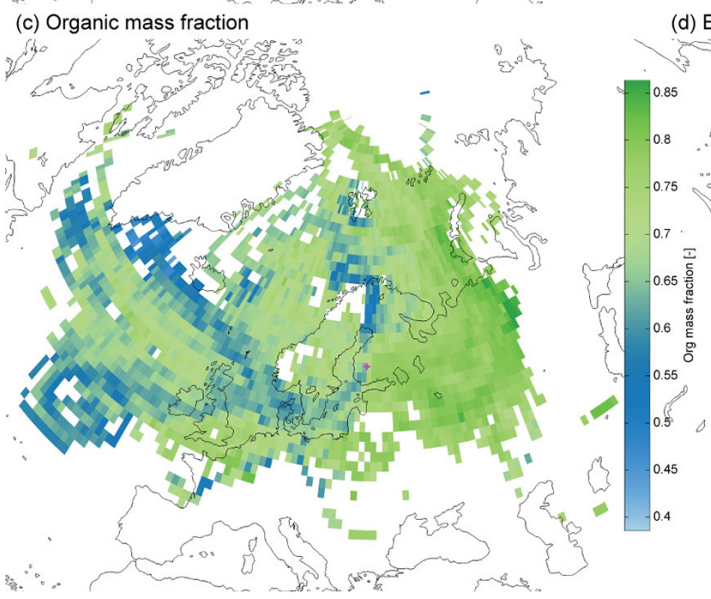

(d) Equivalent black carbon concentration

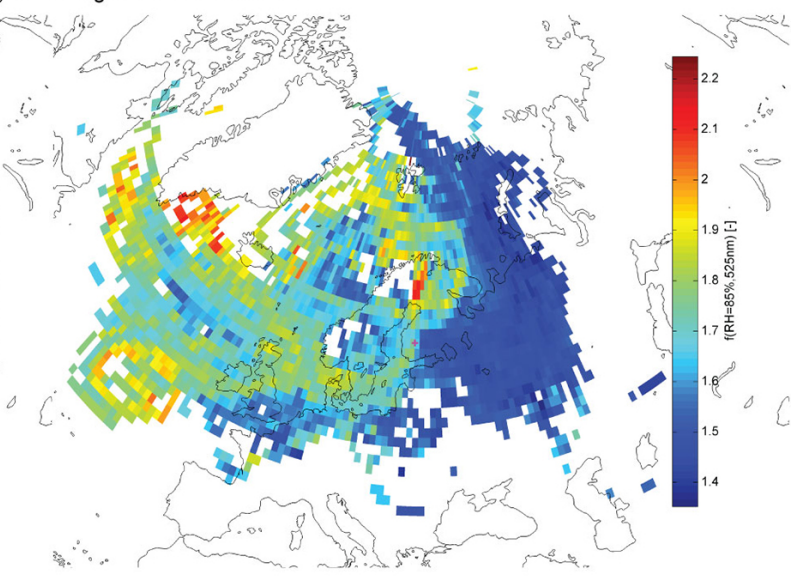

tis

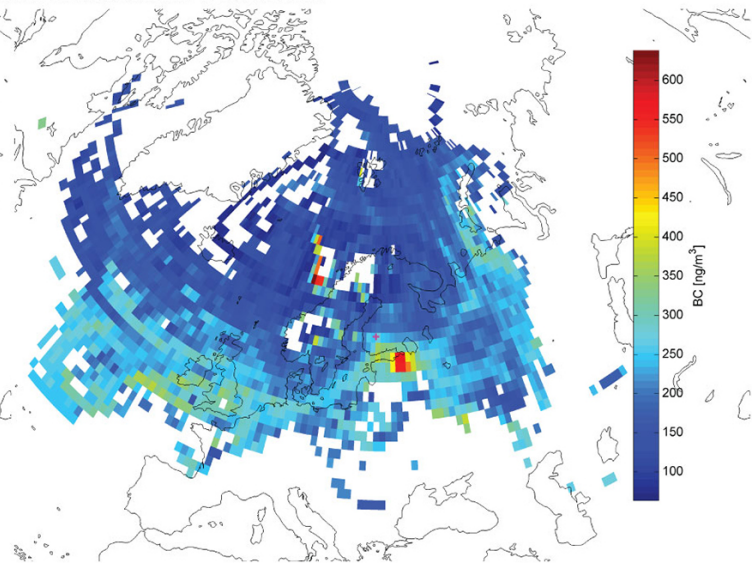

Figure 4. Results of the trajectory analysis (10-day backward calculations of air masses arriving at Hyytiälä, black cross, averaged on a $1^{\circ} \times 1^{\circ}$ grid). (a) Total surface residence time, (b) scattering enhancement factor (at $\mathrm{RH}=85 \%$ and $525 \mathrm{~nm}$ ), (c) organic mass fraction, (d) equivalent black carbon concentration. Only concurrent times are shown when all instruments were operated in parallel.
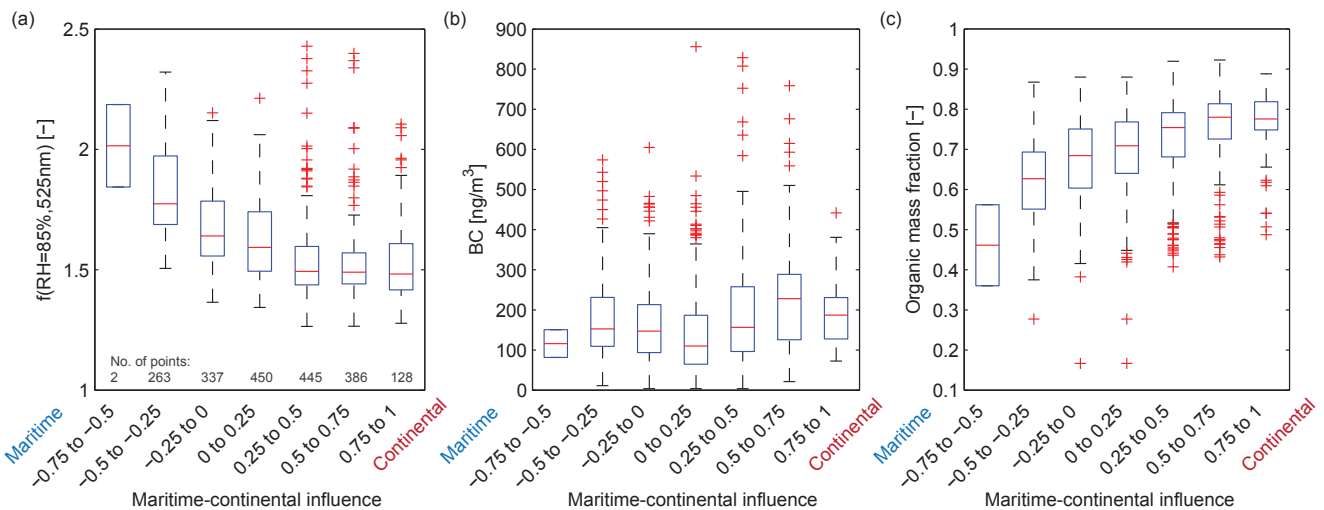

Figure 5. Box plots of the (a) scattering enhancement $f(\mathrm{RH}=85 \%, 525 \mathrm{~nm})$, (b) equivalent black carbon concentration and (c) organic mass fraction vs. the factor indicating the maritime and continental influence (see Eq. 4; as boundary: -1 would be a trajectory only traversing over oceans, +1 would be an air mass only traversing over land). The central red mark is the median, the edges of the box are the 25 th and 75th percentiles and the error bars show the extent to the most extreme data points that are not considered as outliers, while the outliers are plotted individually (red crosses). Only concurrent times are shown when all instruments were operated in parallel. The number of points are given in Panel (a). 
meteorological parameters. No clear and significant dependency was found when compared to the single scattering albedo, aerosol size distribution parameters (total number concentration and mean size), wind direction or wind speed. An exception was the small inverse correlation $\left(R^{2}=0.45\right)$ that was found for the scattering Ångström exponent (only when using the 450 and $525 \mathrm{~nm}$ scattering coefficients) and the total particle surface area. This can probably be explained by the fact that an increased concentration of mainly smaller particles (increased Ångström exponent) were also composed of more organic components (lower hygroscopicity), which overall caused a decreased $f(\mathrm{RH})$. This is also seen in the trajectory analysis, which revealed that air masses from the east showed generally a higher Ångström exponent similar to the organic mass fraction $F_{\text {org }}$ (see Fig. 4 c).

\subsection{Comparison to the chemical composition measurements}

The reason for the low $f(\mathrm{RH})$ at Hyytiälä can be explained by the dominance of organic substances in the particle's chemical composition, which leads to lower particle hygroscopicity. As an example, the fit-parameter $\gamma$ (Eq. 2) at $\lambda=525 \mathrm{~nm}$ is plotted in Fig. 6 as a function of the organic mass fraction $F_{\text {org }}$. The linear regression shows a clear anti-correlation (squared Pearson's correlation coefficient: $\left.R^{2}=0.77\right)$ with a decrease in $\gamma$ with increasing $F_{\text {org }}$ (i.e. $\gamma(525 \mathrm{~nm})=(-0.71 \pm 0.15) \cdot F_{\text {org }}+(0.76 \pm 0.11)$; retrieved from a weighted bivariate fit according to York et al., 2004, taking the SD of the average values as an input for the uncertainty calculation). The dominance of the organic mass fraction (mean \pm SD: $0.7 \pm 0.11$ ) clearly determines the low values of $\gamma$ and thus the low $f(\mathrm{RH})$ observed at Hyytiälä. For comparison, the values measured at Melpitz, Germany, are added to Fig. 6 (for more details see Zieger et al., 2014). The organic mass fraction at Melpitz of submicrometer particles was substantially lower than at Hyytiälä (mean \pm SD: $0.23 \pm 0.10$ ). Although the $\gamma$ values for Melpitz were measured at a different time of year (winter) and showed a higher variability $\left(R^{2}=0.50\right)$, they almost line up linearly with the observations made at Hyytiälä. Due to measurement restrictions the total mass at Melpitz was only differentiated between black and organic carbon, while the total mass at Hyytiälä is determined from the elemental carbon of the EC / OC analysis (organic carbon is assumed to be included in the ACSM organic mass fraction). The ammonia mass fractions at Hyytiälä and Melpitz are also linearly correlated, while the sulphate mass fraction did not show a joint linear behaviour with the Melpitz data. The reason is that the aerosol found at Melpitz during the winter months also contained large amounts of nitrate which mainly formed ammonium nitrate (with a higher hygroscopicity than organic aerosol), while the nitrate contribution at Hyytiälä was very small and the sulphate mainly formed ammonium sulphate

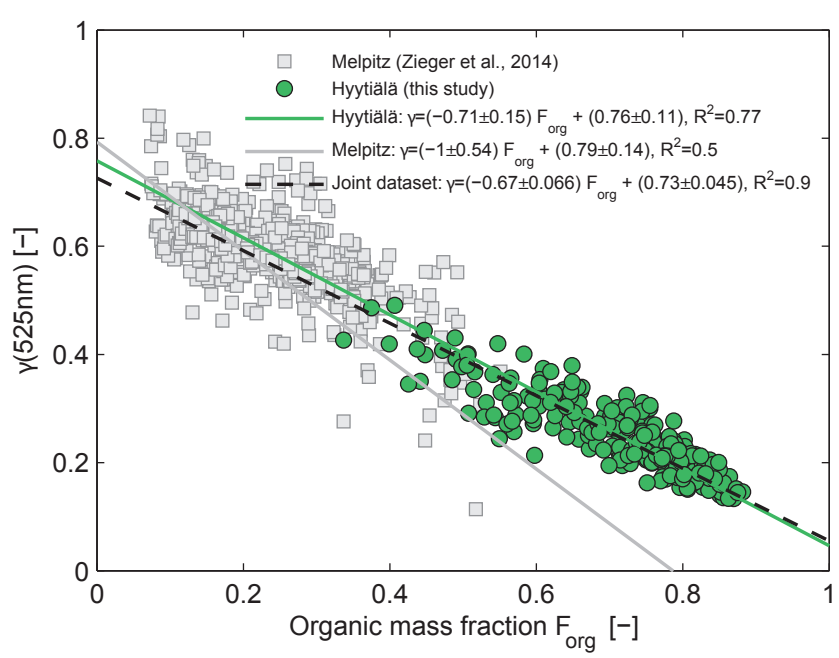

Figure 6. The fit-parameter $\gamma$ (for $\lambda=525 \mathrm{~nm}$ ) vs. the organic mass fraction $F_{\text {org }}$ measured at Hyytiälä (green bullets) and Melpitz, Germany (grey squares). The solid and dashed lines represent the corresponding bivariate weighted linear regressions.

or ammonium bisulphate, which together with the organic contribution lead to a generally lower hygroscopicity.

\subsection{A simplified parametrization for $f(\mathrm{RH})$}

A summary of the linear fit parameters of $\gamma$ vs. the chemical mass fractions is shown in Table 3 for the components which showed a clear linear behaviour. The inorganic mass fractions, mainly sulphate and ammonia, are clearly positively correlated with $\gamma$ and $f(\mathrm{RH})$, in contrast to the anticorrelated organic mass fraction. This allows the use of continuously performed chemical composition measurements at Hyytiälä to predict $f(\mathrm{RH})$ whether a humidified nephelometer is operated. It can be done by taking the total organic or inorganic mass fraction as a proxy for $f(\mathrm{RH})$ and using the linear regression parameters given in Table 3 to calculate $\gamma$ for each wavelengths. $f(\mathrm{RH})$ then follows by using Eq. (2), assuming an intercept of $a=1$. The variance of the intercept $a$ can be used to estimate an uncertainty of the $f(\mathrm{RH})$ prediction (see Table 1).

Numerical parametrizations of $f(\mathrm{RH})$ using chemical mass fractions are only sparsely published. Quinn et al. (2005) proposed a similar parametrization of $\gamma$ using the mass fraction of organic matter and sulphate $\left(\gamma_{s}=\right.$ $-0.6 \cdot \widetilde{F}_{\text {org }}+0.9$ with $\widetilde{F}_{\text {org }}=C_{\text {org }} /\left(C_{\text {org }}+C_{\mathrm{SO}_{4}}\right)$ and $\gamma_{s}=$ $\ln (f(\mathrm{RH})) / \ln \left(\left(1-\mathrm{RH}_{\mathrm{ref}}\right) /(1-\mathrm{RH})\right)$, which is similar to Eq. (2) if $a=1 ; \mathrm{RH}_{\text {ref }}$ denotes the dry reference $\mathrm{RH}$ ). This parametrization is limited to aerosol dominated by the accumulation mode and is only given for $\lambda=550 \mathrm{~nm}$ (P. Quinn, personal communication, May 2015). Our results (if calculated in the same manner as described in Quinn et al., 2005) show the same decreasing trend of $\gamma_{s}$ (for example for Hyytiälä: $\gamma_{s}=-0.79 \cdot \widetilde{F}_{\text {org }}+0.96$ and Melpitz: $\gamma_{s}=-0.35$. 
Table 3. Parameters retrieved from a linear regression of the different chemical mass fractions $F_{i}$ (ACSM and EC / OC) vs. $\gamma$ (fit parameter for $f(\mathrm{RH})$ ) for the different nephelometer wavelengths. The calculated uncertainty of slope and intercept of the used bivariate weighted fit (York et al., 2004) are given in parenthesis. The parameters for $\mathrm{NO}_{3}, \mathrm{Cl}$ and $\mathrm{EC}$ are not given due to the low correlation. The lower part (marked by an asterisk) shows the linear regression parameters calculated in the same manner for the joint data set of Hyytiälä (this study) and Melpitz (Zieger et al., 2014) for the components which showed a joint linear behaviour. These values can be used to predict $f$ (RH) by using Eq. (2) (assuming an intercept of $a=1$ ).

\begin{tabular}{|c|c|c|c|c|c|c|c|c|c|}
\hline \multirow[t]{2}{*}{$F_{i}$} & \multicolumn{3}{|c|}{ Slope } & \multicolumn{3}{|c|}{ Intercept } & \multicolumn{3}{|c|}{$R^{2}$} \\
\hline & $450 \mathrm{~nm}$ & $525 \mathrm{~nm}$ & $635 \mathrm{~nm}$ & $450 \mathrm{~nm}$ & $525 \mathrm{~nm}$ & $635 \mathrm{~nm}$ & $450 \mathrm{~nm}$ & $525 \mathrm{~nm}$ & $635 \mathrm{~nm}$ \\
\hline Organic & $-0.70(0.14)$ & $-0.71(0.15)$ & $-0.79(0.18)$ & $0.74(0.10)$ & $0.76(0.11)$ & $0.85(0.13)$ & 0.79 & 0.77 & 0.79 \\
\hline $\mathrm{NH}_{4}$ & 3.19 (2.27) & $3.37(2.55)$ & $3.56(2.76)$ & $0.03(0.14)$ & $0.03(0.16)$ & $0.05(0.18)$ & 0.50 & 0.47 & 0.58 \\
\hline $\mathrm{SO}_{4}$ & $1.00(0.16)$ & $0.99(0.16)$ & $1.15(0.21)$ & $0.08(0.02)$ & $0.09(0.02)$ & $0.11(0.03)$ & 0.79 & 0.80 & 0.78 \\
\hline $\mathrm{NO}_{3}$ & - & - & - & - & - & - & 0.05 & 0.05 & 0.11 \\
\hline $\mathrm{Cl}$ & - & - & - & - & - & - & 0.00 & 0.00 & 0.00 \\
\hline $\mathrm{EC}$ & - & - & - & - & - & - & 0.01 & 0.00 & 0.03 \\
\hline Inorganic & $0.69(0.18)$ & $0.79(0.18)$ & $0.79(0.23)$ & $0.06(0.04)$ & $0.05(0.05)$ & $0.08(0.06)$ & 0.80 & 0.79 & 0.79 \\
\hline Organic* & $-0.64(0.06)$ & $-0.67(0.07)$ & $-0.69(0.07)$ & $0.70(0.04)$ & $0.73(0.04)$ & $0.77(0.05)$ & 0.90 & 0.90 & 0.87 \\
\hline $\mathrm{NH}_{4} *$ & $3.44(1.44)$ & $3.56(1.50)$ & $3.54(1.51)$ & $0.02(0.11)$ & $0.02(0.11)$ & $0.05(0.12)$ & 0.82 & 0.84 & 0.83 \\
\hline Inorganic* & $0.76(0.13)$ & $0.78(0.14)$ & $0.83(0.16)$ & $0.04(0.04)$ & $0.05(0.04)$ & $0.07(0.04)$ & 0.87 & 0.88 & 0.87 \\
\hline
\end{tabular}

$\widetilde{F}_{\text {org }}+0.81$ at $\left.\lambda=525 \mathrm{~nm}\right)$. However, both data sets do not show the same joint linear trend anymore because the organic mass fraction of the parametrization by Quinn et al. (2005) is calculated using the organic and sulphate concentrations only. The aerosol at Melpitz, however, had a significant contribution of nitrate, ammonia and black carbon which needs to be included in the parametrization to retrieve a reliable estimate on $f(\mathrm{RH})$. In a more recent study, Zhang et al. (2015) parametrized their measurements of $f(\mathrm{RH})$ from the Yangtze River Delta region in China in a similar way as Quinn et al. (2005) but adding also nitrate to the organic mass fraction. A linear relationship of $\gamma_{s}=-0.42 \cdot \widetilde{F}_{\text {org }}+0.54$ with $\widetilde{F}_{\text {org }}=C_{\text {org }} /\left(C_{\text {org }}+C_{\mathrm{SO}_{4}}+C_{\mathrm{NO}_{3}}\right)$ was found, which compares better to our results; however, the ammonia and black carbon components are still missing in the linear relationship presented by Zhang et al. (2015).

Table 3 also states the linear regression parameters for the joint Hyytiälä and Melpitz data sets. As mentioned above, the organic and the total inorganic mass fractions showed a common linear behaviour and thus a more general rule to predict $f(\mathrm{RH})$ from aerosol chemical composition measurements can be derived. Individual inorganic components like sulphate or nitrate may show different functional dependencies individually for each site; however, as the comparison to Quinn et al. (2005) and Zhang et al. (2015) showed, it is important to include all major chemical constituents when deriving a general parametrization of $\gamma$ or $f(\mathrm{RH})$ as has been done here. Our parametrization for Hyytiälä is strictly spoken only valid for the summer months when the fine mode is clearly dominated by less hygroscopic organic substances. Verification during other seasons and adding other sites is needed to allow a generalization of these findings. The addition of the Melpitz findings from Zieger et al. (2014) should only be seen as a first step. Additionally, the parametrization may not be valid during periods with substantially different coarse mode contribution which can have a potentially large impact on the total $f(\mathrm{RH})$ (Zieger et al., 2013).

\subsection{Extrapolation to the atmospheric column using aircraft measurements}

The in situ measurements were extrapolated to the atmospheric column using regular airborne profile measurements that were performed during the second half of May until mid of June 2013. In total 17 profiles with collocated cloud-free SPM measurements on the ground were available. The measurements were binned in $200 \mathrm{~m}$ wide height levels (starting at $200 \mathrm{~m}$ a.s.l.). The profile flights time took on average $2.5 \mathrm{~h}$ and included up to three full ascends and descends. A comparison of the aircraft measurement at the lowest flight level (200-400 ma.s.l.) to the ground-based CPC shows a good agreement $\left(R^{2}=0.80\right.$, linear regression: $\left.N_{\text {tot }}^{\text {Cessna }}=1.17 N_{\text {tot }}^{\text {ground }}-142 \mathrm{~cm}^{-3}\right)$ and slightly less particles by the ground CPC.

The AOD is defined as the vertical integral of the particle light extinction coefficient $\sigma_{\mathrm{ep}}$ :

$\operatorname{AOD}(\lambda)=\int_{h_{0}}^{h_{1}} \sigma_{\mathrm{ep}}(\lambda, h) \mathrm{d} h$,

where $h_{0}$ is the surface altitude, $h_{1}$ is usually the top of the atmosphere (e.g. when measured by a SPM) and $\lambda$ the wavelength. Here, $h_{1}$ is the height of the highest profile point reached by the aircraft.

To obtain the AOD from the in situ measurements the dry ground-based measured $\sigma_{\mathrm{sp}, \text { dry }}$ (nephelometer) and $\sigma_{\text {ap,dry }}$ 
(aethalometer) were first transformed to the respective SPM wavelength using the Ångström law:

$\sigma_{\mathrm{sp}}(\lambda)=k \lambda^{-\alpha_{\mathrm{sp}}}$,

where $k$ is the turbidity coefficient and $\alpha_{\mathrm{sp}}$ the scattering Ångström exponent. Equation (6) can be formulated for $\sigma_{\text {ap,dry }}$ in an analogous way. The sum of $\sigma_{\text {sp,dry }}$ and $\sigma_{\text {ap,dry }}$ yields the particle light extinction coefficient $\sigma_{\text {ep,dry. }}$. We have limited the extrapolation to SPM wavelengths that are close to the nephelometer wavelengths to reduce the involved uncertainties. The in situ AODs are therefore only calculated between 440 and $870 \mathrm{~nm}$. To calculate $\sigma_{\mathrm{ep}, \mathrm{dry}}(\lambda, h)$ at different altitudes the total particle number concentration $N_{\text {tot }}$ as measured by the airborne CPC was used as a scaling factor $c(h)$. The in situ AOD for the dry case then calculates as follows

$$
\begin{gathered}
\operatorname{AOD}_{\text {dry }}^{\text {in situ }}(\lambda)=\int_{h_{0}}^{h_{1}} c(h) \sigma_{\text {ep, dry }}^{\text {ground }}(\lambda) \mathrm{d} h, \\
\text { with } \quad c(h)=\frac{N_{\text {tot }}(h)}{N_{\text {tot }}\left(h_{0}\right)} .
\end{gathered}
$$

For the ambient in situ AOD, the particle hygroscopic growth at $\mathrm{RH}$ of the different altitudes was now taken into account by using the ground-based measured $f(\mathrm{RH})$ and assuming that it does only depend on RH. This assumption means that the particle chemical composition and intensive size distribution parameter do not change with altitude. Eq. (7) then changes to

$$
\begin{aligned}
\operatorname{AOD}_{\text {amb. }}^{\text {in situ }}(\lambda) & =\int_{h_{0}}^{h_{1}} c(h)\left(f(\mathrm{RH}, \lambda) \sigma_{\mathrm{sp}, \text { dry }}^{\text {ground }}(\lambda)\right. \\
& \left.+\sigma_{\text {ap , dry }}^{\text {ground }}(\lambda)\right) \mathrm{d} h .
\end{aligned}
$$

Note that the absorption coefficient is assumed not to change with RH. This is a reasonable assumption at Hyytiälä due to the fact that the scattering enhancement exceeds the absorption enhancement (Nessler et al., 2005) and, even more importantly, due to the dominance of the light scattering (i.e. campaign average for the single scattering albedo $\omega_{0}=0.94 \pm 0.03$ at $\lambda=525 \mathrm{~nm}$, see Table 2), which in total will only induce a small error. The $f(\mathrm{RH})$ is linearly inter- or extrapolated to the SPM wavelengths. To test the influence of the layer above the maximum flight altitude an exponential decrease of the total number concentration was assumed (with $c(h)=c\left(h_{i}\right) \exp (-0.25 h)$ above the maximum flight altitude, where $c\left(h_{i}\right)$ is the scaling factor of the last height bin and $h$ the altitude up to $7 \mathrm{~km}$ ). This is a reasonable assumption only for cases without clear elevated layers, which was most likely only given for the first half of the airborne observation period (see Sect. 6.4). The in situ AOD with the exponential decreasing profile above the maximum
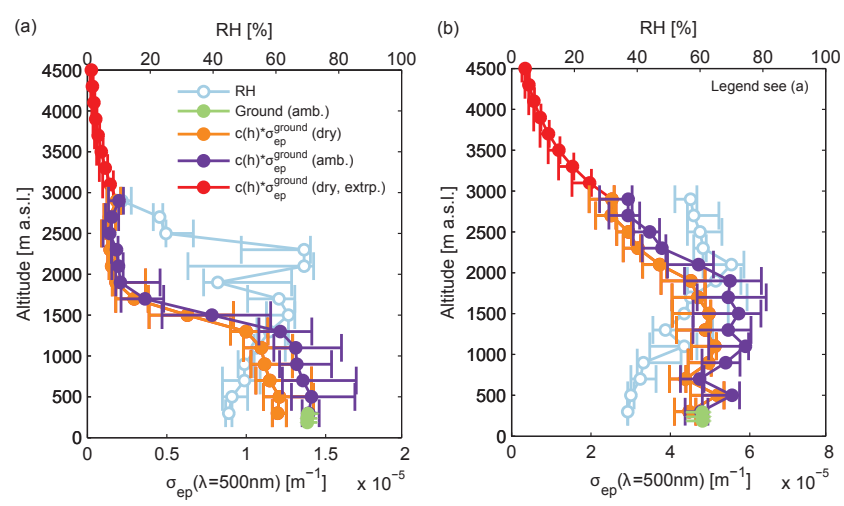

Figure 7. Example of the ground-based in situ measurements extrapolated to the atmospheric column. Particle light extinction coefficient $\sigma_{\mathrm{ep}}$ (at $\lambda=500 \mathrm{~nm}$ ) measured at the surface at ambient $\mathrm{RH}$ (along the tower at 17, 67 and $124 \mathrm{~m}$; green bullets), surface extinction coefficient weighted with the relative changes in the total number concentration measured by the aircraft CPC (dry, orange points) and at ambient conditions (violet points) with the RH measured on board the aircraft (blue points, upper axis). The red points are dry values of $\sigma_{\mathrm{ep}}$ above the maximum flight altitude assuming an exponential decreasing particle concentration. The error bars denote the 25th and 75th percentile values. (a) Result for the 23 May 2013. (b) Result for the 02 June 2013.

flight level is only calculated for the dry case since no RH measurements are available above the maximum flight altitude.

To calculate the in situ AOD the atmosphere above was separated into $200 \mathrm{~m}$ wide levels in which the CPC measurements were averaged to determine $c(h)$ for each layer starting at $200 \mathrm{~m}$ a.s.l. (close to the top of the canopy and location of the SPM). Two example profiles showing the in situ derived profiles are presented in Fig. 7. For comparison, the ambient extinction coefficient measured at the ground is shown together with the RH profile. As a test for the variability, the calculations were repeated by using the 25 th and 75 th percentiles as lower and upper boundary respectively. In the first example, the top of the ML is clearly seen at around $1500 \mathrm{~m}$. The particle light extinction coefficient sharply decreases above the ML. The RH effect is significant but not very strong due to the low hygroscopicity of the organicdominated aerosol at Hyytiälä and the low RH profile during that time of day (RH varied within the ML between 50 and $70 \%$ while it decreased to $20 \%$ above $2000 \mathrm{~m}$ ). Integrating the ambient extinction coefficient profile yields an $\mathrm{AOD}_{\mathrm{amb}}^{\text {in situ }}$ of 0.018 at $\lambda=500 \mathrm{~nm}$, while the SPM measured a value of 0.055 . The second profile example (Fig. 7b) shows the result for the 02 June, where no clear ML transition can be observed. The extinction coefficient still is elevated even at the maximum flight level of $2700 \mathrm{~m}$. An integration of the ambient extinction coefficient profile gives an $\mathrm{AOD}_{\mathrm{amb}}^{\mathrm{in} \text { situ }}$ of 0.1 at $\lambda=500 \mathrm{~nm}$, while the SPM measured a value of 0.37 . The time series for all profile retrieved AOD values and the 


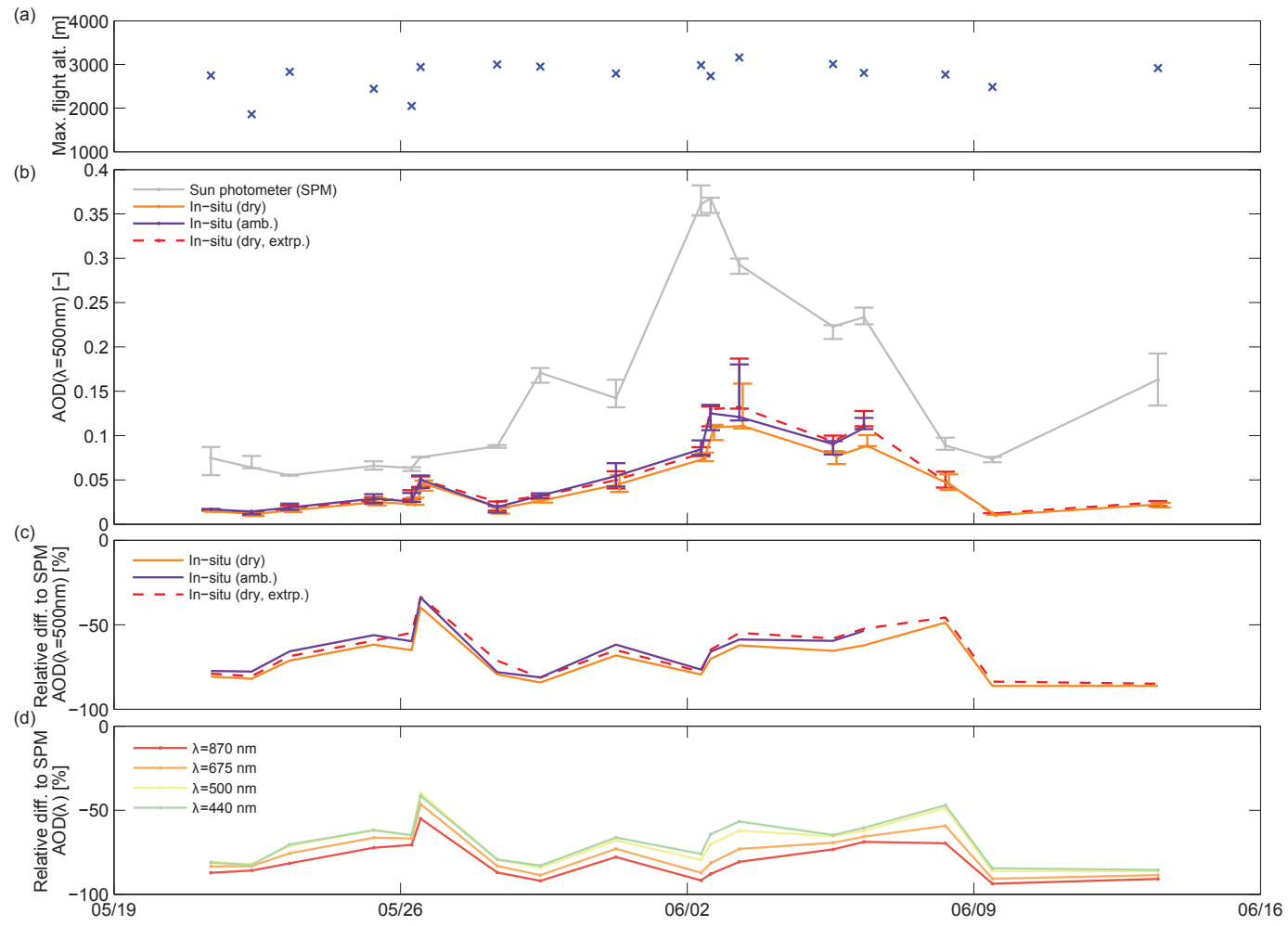

Figure 8. (a) Time series of the maximum altitude during the aircraft profiling. (b) Time series of the AOD at $\lambda=500 \mathrm{~nm}$ measured by the sun photometer (SPM, grey curve), determined from the ground-based dry extinction coefficient and the airborne CPC as scaling factor (orange curve) and determined from the ground-based extinction coefficient at ambient conditions (violet curve). The red dashed curve represents the in situ derived AOD when an exponential decreasing profile is assumed above the maximum flight altitude (at dry conditions). The error bars denote the distance to the 25th and 75th percentile values, while the centre point gives the median value for each profile. (c) Relative difference of in situ derived AOD compared to the SPM measurement ((AOD in-situ $\left.-\mathrm{AOD}_{\mathrm{SPM}}\right) / \mathrm{AOD}_{\mathrm{SPM}} \cdot 100 \%$ at $\left.\lambda=500 \mathrm{~nm}\right)$. (d) Relative difference of dry in situ derived AOD compared to the SPM measurement for different SPM wavelengths.

SPM measured ones are depicted in Fig. 8 for $\lambda=500 \mathrm{~nm}$ together with the maximum flight altitude. The in situ derived values follow the course in time of the direct AOD values of the SPM. However, they are 2-3 times smaller than the directly obtained ones (Fig. 8c). Figure $8 \mathrm{~b}$ and $\mathrm{c}$ also reveals that the addition of an assumed exponential decreasing profile above approx. $3 \mathrm{~km}$ only marginally leads to an increase of the in situ derived dry AOD. This points towards the fact that most of the particles were captured by the aircraft profiling, if the assumption of an exponential decrease in particle number concentration is valid. However, this assumption is most likely not valid for the second half of the aircraft profiling period. As can be seen in Fig. 8b, the AOD increases in the beginning of June due to long-range transport of mineral dust in elevated layers (see Sect. 6.4). The WetNeph was not in continuous operation between 08 and 15 June 2013 due to computer failures and thus the ambient $\mathrm{AOD}_{\text {amb. }}^{\text {in situ }}$ was not retrieved for this period.

The calculations were done for all SPM wavelengths between 440 and $870 \mathrm{~nm}$ which are close to the spectral region of the nephelometer. Figure $8 \mathrm{~d}$ shows that the relative differ- ence of the dry in situ derived AOD to the SPM measured values increases for larger wavelengths. These differences are more pronounced for the period of potential long-range transported mineral dust.

The following hypotheses are brought forward to explain the clear disagreement between in situ derived and directly measured AOD:

1. assumptions made to calculate $\mathrm{AOD}_{\mathrm{in}-\text { situ; }}$;

2. inconsistencies within the in situ measurements;

3. missing coarse mode particles $\left(D_{\mathrm{p}}>1 \mu \mathrm{m}\right)$ and general sampling losses within the ground-based in situ measurements;

4. removal by dry deposition within the canopy;

5. aerosol layers above the maximum flight altitude.

The hypotheses will be discussed in detail in the following section. 


\section{Discussion}

\subsection{Influence of general assumptions being made}

The main assumptions that were made in Sect. 5.4 can all have a potential influence on the disagreement between in situ derived and measured AOD values. The first main assumption is to use the total particle number concentration as scaling factor $c(h)$ in Eqs. (7) and (8). It should be noted here that the results are in a similar range if the particle surface is being used to calculate $c(h)$; however, that factor would omit optically active particles above the upper size limit of the airborne SMPS (see Fig. 11b) and therefore we prefer to take the total concentration to determine $c(h)$.

To calculate the ambient extinction, it was assumed in Eq. (8) that the particle light absorption enhancement is negligible. As mentioned above, this is justified for this site due to the low absorption enhancement effect compared to the scattering effect and the overall dominance of particle light scattering when determining the particle light extinction coefficient (Nessler et al., 2005).

For the ambient case, it was additionally assumed that the $f(\mathrm{RH})$ is the same within the column as measured at ground and therefore only depends on the RH at different altitudes. This assumption implies that the chemical composition (hygroscopicity) and mean size is constant throughout the atmospheric column. This assumption is most likely fulfilled for a well-mixed boundary layer; however, it will not be valid for lofted or separate layers during episodes with longrange transported air masses. During the summer months at Hyytiälä, however, the columnar RH was always moderate and low in addition to the fact that particles are generally less hygroscopic at this boreal site and, therefore, the overall effect of the constant $f(\mathrm{RH})$ assumption was probably small compared to the hypotheses discussed below.

\subsection{Consistency of in situ measurements: optical closure study}

To prove the consistency of the optical and microphysical aerosol in situ measurements, a closure study based on Mie theory (Bohren and Huffman, 2004) was performed. The particles were assumed to be spherical, homogeneous and internally mixed. As input, the particle number size distribution measured by the DMPS and APS was used (the APS and DMPS size distributions were merged at the last DMPS size bin). The complex refractive index was inverted from the dry scattering (nephelometer) and absorption coefficient (aethalometer) measurements and the measured particle number size distribution using Mie theory (Zieger et al., 2010). Only the measurements from the continuous aerosol monitoring program were used for the retrieval since they were also located inside the aerosol cottage. The calculation was done incorporating the TSI nephelometer illumination sensitivity and the specific scattering angles to avoid the trun- cation error (Anderson et al., 1996). For $\lambda=450 \mathrm{~nm}$ a mean value for the RI of $(1.56 \pm 0.07)+(0.008 \pm 0.005) i$ was calculated, while $(1.53 \pm 0.06)+(0.008 \pm 0.005) i$ and $(1.50 \pm$ $0.07)+(0.008 \pm 0.005) i$ were calculated for $\lambda=550 \mathrm{~nm}$ and $\lambda=700 \mathrm{~nm}$ respectively. These retrieved real parts of the RI for Hyytiälä are close to the values of ammonium sulphate (e.g. $1.536+10^{-7} i$ at $\lambda=450 \mathrm{~nm}$; Toon et al., 1976). The result of the Mie calculations is shown in Fig. 9a, in which the relative differences between prediction (Mie calculation) and measurement are shown for all nephelometer wavelengths. The monitoring nephelometer (located in the cottage) is in almost perfect agreement to the calculation which is reasonable since the same measurement was used to retrieve the RI. However, the little variation proves that it is justified to use an average and fixed RI for each wavelength for the entire period. The calculated $\sigma_{\mathrm{sp} \text {,dry }}$ for the dry nephelometer used within the WetNeph system (located in the campaign containers) are clearly underestimated by the model calculations (on average 8-30\%, see Fig. 9a). This corresponds to general differences between the dry monitoring nephelometer in the cottage measuring less particle light scattering than the reference nephelometer of the WetNeph located inside the container (see Fig. 9b). The lower measured scattering coefficients of the cottage nephelometer are in correspondence to the underestimation of the measured particle number size distribution, which is an input to the Mie calculation. Therefore, particle number concentration and light scattering measurements of the monitoring measurement inside the cottage were affected by the same loss effect. Almost the same result is obtained when the RI of ammonium sulphate is taken. Small parts of the disagreement could come from general calibration issues of the nephelometers used in the WetNeph set-up. The larger variation of the WetNeph reference nephelometer (the error bars denote the 25 th and 75 th percentile values) suggests that the container site experienced more variation in aerosol concentration compared to the cottage site inside the forest.

The differences in the scattering coefficients cancel out when the scattering enhancement is calculated. In a first test, the hygroscopic growths factors $g(\mathrm{RH})$ (Eq. 3) of the HTDMA were taken (details on the $f(\mathrm{RH})$ calculation can be found in Zieger et al., 2013). The $g(\mathrm{RH})$ values were interpolated between the measured dry diameters of $D_{\mathrm{p}}=30$ and $145 \mathrm{~nm}$. Above $145 \mathrm{~nm}$, the values of $g(\mathrm{RH})$ were assumed to be the same as the one measured at $D_{\mathrm{p}}=145 \mathrm{~nm}$ (similar for $D_{\mathrm{p}}=30 \mathrm{~nm}$ ). The calculated values of $f(\mathrm{RH})$ using the HTDMA measurements lie on average within the range of the measured values (Fig. 9a). A slight disagreement for the larger wavelengths (on average $12 \%$ at $635 \mathrm{~nm}$ ) is found. As second test, the values of $g(\mathrm{RH})$ were calculated using the ACSM and EC / OC measurements. The value for pure organics was first assumed to be $g_{\text {org }}(\mathrm{RH}=90 \%)=1.2$ (Fierz-Schmidhauser et al., 2010b; Zieger et al., 2014) and secondly assumed to be $g_{\text {org }}(\mathrm{RH}=90 \%)=1.05$, a value recently derived for isoprene-dominated organics at Hyytiälä 

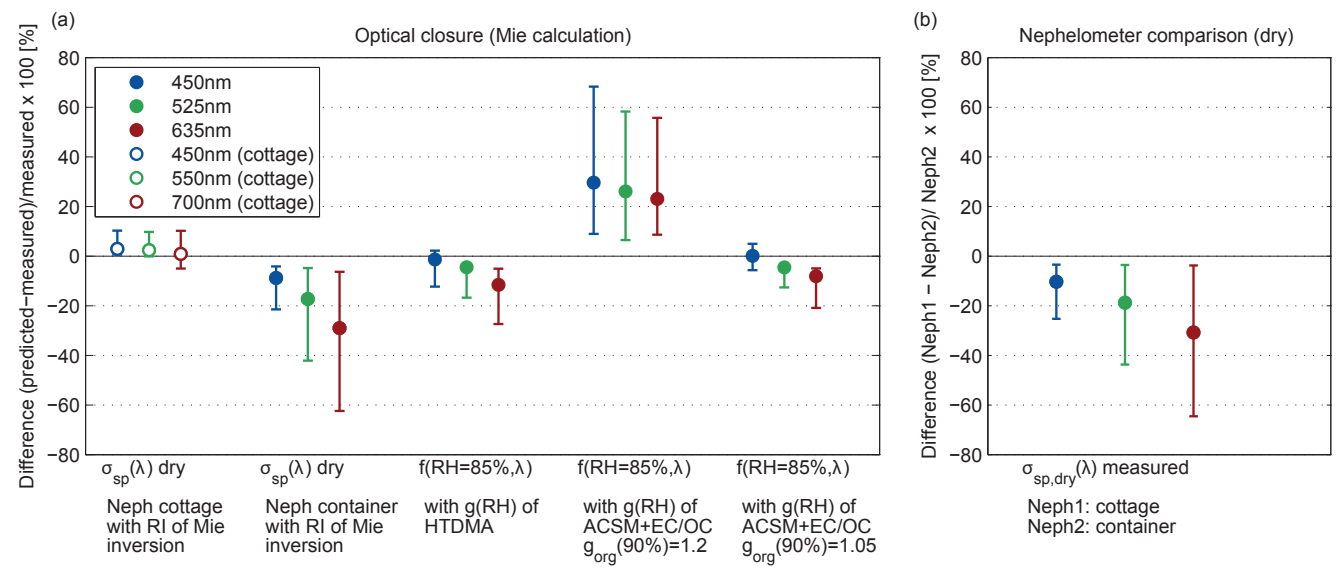

Figure 9. (a) Result of the optical closure study. Relative differences of the predicted to measured scattering coefficient (dry) and scattering enhancement factor (at $\mathrm{RH}=85 \%$ ) for the different nephelometer wavelengths. The circle denotes the median value and the error bars the 25 th and 75 th percentile values. (b) Comparison of the dry nephelometer measurements $\left(\sigma_{\mathrm{sp} \text {,dry }}\right)$ between cottage (monitoring) and container (WetNeph). The values of the cottage nephelometer were interpolated using Eq. (6).

(Riipinen et al., 2015). The calculated values using the original value of $g_{\text {org }}(\mathrm{RH}=90 \%)=1.2$ are systematically higher than the direct measurements $(\approx 30 \%)$, while the lower value of $g_{\text {org }}(\mathrm{RH}=90 \%)=1.05$ delivers an improved agreement. This points towards the importance of the hygroscopic growth factor, which is especially for low hygroscopic substances important when calculating $f(\mathrm{RH})$ (see Fig. A1 in Zieger et al., 2013).

Summarizing the optical closure study, one can conclude that the different in situ measurements provide consistent results. However, the differences found in the scattering coefficients measured by the monitoring and reference nephelometers point towards losses. Partitioning effects of semi-volatile organics (Donahue et al., 2006) or nitrate components (due to the low concentration to a lesser extent, see Table 2) that could have caused a potential decrease in the overall particle properties cannot be ruled out completely. Although it is believed to have a minor effect during the summer months and daytime in situ measurements at this site. Smaller differences can additionally be explained by the simplified assumptions taken for the Mie calculations (e.g. internal mixture, homogeneous and spherical particles, no size dependence of the refractive index, specific values for $g(\mathrm{RH})$ ).

\subsection{Particle losses}

The SPM was placed on a tower above the forest canopy ( 198 ma.s.1.), while the in situ measurements were performed on ground below the canopy ( $\sim 180 \mathrm{~m}$ a.s.l.). Particles may have been lost within the canopy by dry deposition before reaching the inlet (Grönholm et al., 2007; Buzorius et al., 2003; Petroff et al., 2008), which includes removal through Brownian diffusion (mainly for fine mode particles below $D_{\mathrm{p}}<100 \mathrm{~nm}$ ) or through impaction or interception (mainly for coarse mode particles above $D_{\mathrm{p}}>1000 \mathrm{~nm}$ ).
Grönholm et al. (2009) performed aerosol flux measurements using the eddy covariance technique at Hyytiälä and found that only $35 \%$ of the particles penetrated through the canopy at low wind speeds. At higher wind speeds and correspondingly stronger turbulent conditions only $10 \%$ of all particles reached the ground. The study by Grönholm et al. (2009) was performed in spring, while our measurements were done in summer months with probably more turbulence and thus higher deposition losses. In addition, particle losses could have also occurred within the inlet and tubing itself. However, this is rather unlikely since the optical closure study has shown the consistency of the optical and microphysical aerosol measurements.

Figure 10a shows the average particle number size distribution measured at the ground and by the aircraft within the lowest layer. For small particles below $100 \mathrm{~nm}$, the aircraft measured on average higher concentrations (up to $40 \%$ ) than the ground-based instrument. However, for the optically important size range above $100 \mathrm{~nm}$, both size distributions agree surprisingly well. Figure $10 \mathrm{~b}$ depicts the scattering size distribution calculated using the measured size distributions and Mie theory. Here, both size distribution measurements agree until the maximum diameter of the aircraft SMPS is reached. Unfortunately, above $D_{\mathrm{p}}>270 \mathrm{~nm}$ the aircraft did not record the size distribution and thus missed information on the optically important part of the aerosol size spectrum.

The relative disagreement between in situ derived and measured AOD values increased for larger wavelengths (see Fig. 8d), which points towards an influence of large particles which are not sufficiently sampled by the in situ instruments. Figure 11 shows the calculated scattering coarse mode fraction (defined as the scattering coefficient for particles above $D_{\mathrm{p}}>1 \mu \mathrm{m}$ divided by the total scattering coefficient both calculated using Mie theory) for all wavelengths used 

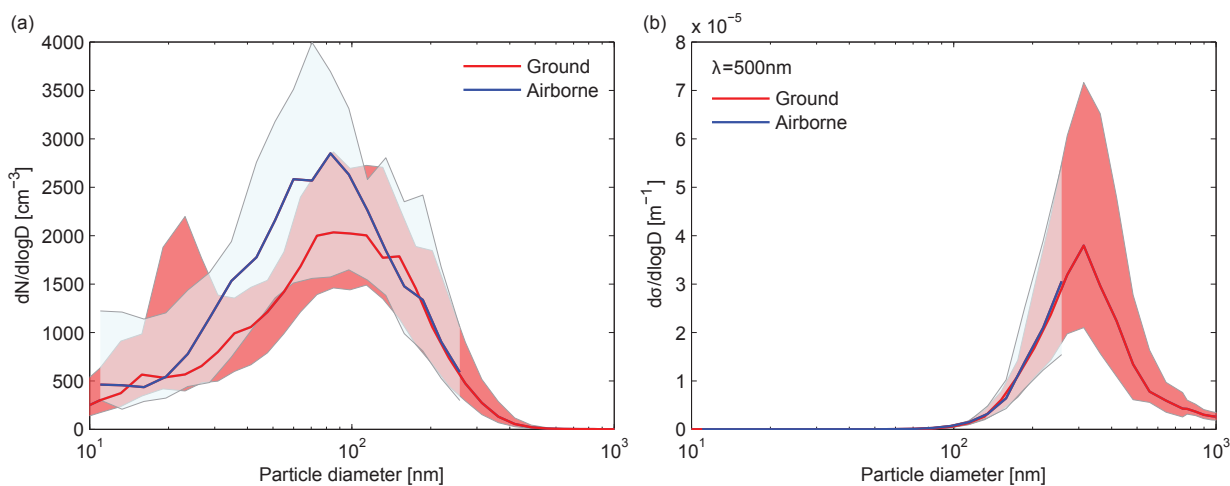

Figure 10. (a) Average particle number size distribution measured at ground and within the lowest flight level by the aircraft (200$400 \mathrm{~m}$ a.s.1.). (b) Aerosol scattering size distribution calculated using Mie theory for the wavelengths of $500 \mathrm{~nm}(\mathrm{RI}=1.51)$. The centre lines show the median, while the corresponding shaded areas denote the 25 th and 75 th percentile values.

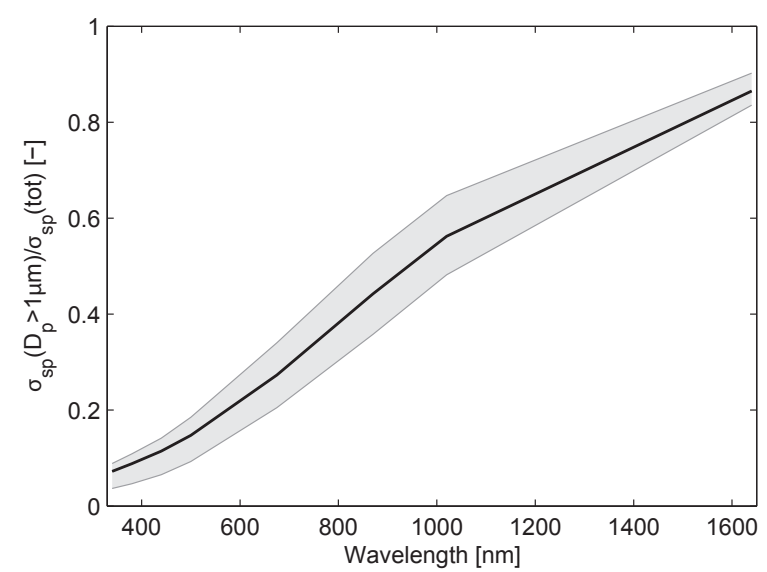

Figure 11. Coarse mode fraction of the particle light scattering coefficient vs. the sun photometer wavelengths. The black centre line shows the median value, while the shaded area denote the 25 th and 75 th percentile value range for the period with airborne measurements.

in the SPM measurements. The calculation was done for all time periods with corresponding profiles using the particle number size distribution measurement on the ground. With increasing wavelength more light scattering will be due to coarse mode particles. At $\lambda=1020 \mathrm{~nm}$, for example, it is already $50 \%$ for the here measured aerosol. A few losses of supermicron particles can therefore explain the observed differences.

The AOD for the fine mode fraction $\left(D_{\mathrm{p}}<1 \mu \mathrm{m}\right)$ was estimated by taking the measured particle number size distribution at ground and applying Mie theory (taking the RI from the Mie inversion, see Sect. 6.2) which results in the extinction coefficient for submicrometer particles only. The calculation of in situ AOD for the fine mode fraction followed in the same manner as described above (using Eq. 8). The comparison of the derived values to the AERONET inverted fine mode AOD is shown in Fig. 12. A high correlation was

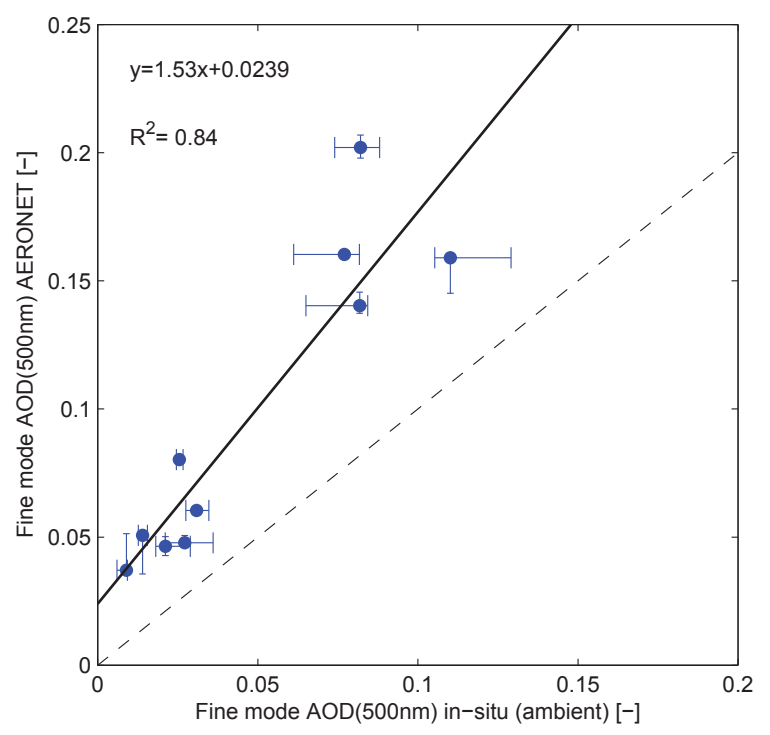

Figure 12. Aerosol optical depth (AOD) of fine mode particles derived from AERONET vs. the in situ derived value using Mie theory and the measured size distribution (at $550 \mathrm{~nm}$ ). The error bars denote the range of the 25 th and 75 th percentile values, while the centre points mark the median value.

found $\left(R^{2}=0.84\right)$ and a linear least-squares regression revealed that the AERONET values were significantly higher (slope of 1.53) compared to the in situ derived values. Again, this indicates that besides the missing coarse mode also the loss of fine mode particles contributed to the found disagreement. These particles could have been fine mode particles above the maximum flight altitude (see Sect. 6.4) or particles possibly lost through dry deposition within the canopy.

\subsection{Elevated layers}

As discussed above, the airborne sampling was only performed to a maximum altitude of $3.2 \mathrm{~km}$. Thus, elevated 
layers contributing to the columnar AOD could have been missed by the aircraft. The time series of the AOD in Fig. 8b already showed an unusual increase of the AOD (to 0.35 at $\lambda=500 \mathrm{~nm}$; starting approximately on the 02 June 2013 ) compared to the average values measured at Hyytiälä $(0.12 \pm$ 0.04, Aaltonen et al., 2012). Figure 13 shows lidar profiles of the aerosol backscatter coefficient (at $\lambda=1064 \mathrm{~nm}$ ) recorded at Kuopio during the airborne campaign. While there are no significant elevated layers before 28 May, clear elevated layers are seen above $3000 \mathrm{~m}$ from 30 May until 03 June. Air mass back trajectories showed that the air originated from the Arabian peninsula and thus could consist of layers of mineral dust particles. In addition, the depolarization channel showed values indicative for non-spherical particles. Figure 13 also gives the percental contribution from the layer above $3 \mathrm{~km}$ and below $7 \mathrm{~km}$ to the total AOD derived by the lidar. For the period before 02 June, 15-25\% of the AOD was attributed to aerosol particles in elevated layers, while elevated layers contributed between 60 and $80 \%$ to the AOD between 02 and 03 June (assuming a constant lidar ratio). These percentages are in correspondence to the relative differences calculated for the in situ derived AOD vs. the measured values by the SPM during the period of long-range transported mineral dust (see Fig. 8d). It should be mentioned that the comparison to the lidar profiles measured at Kuopio is only of qualitative nature to demonstrate the effect of lofted layers due to long-range transport.

\section{Conclusions}

The effect of water uptake on the particle light scattering coefficient was investigated at a boreal site using a humidified nephelometer system. Compared to other major aerosol types the aerosol light scattering enhancement factor $f(\mathrm{RH})$ shows low values with little variation (at $\mathrm{RH}=85 \%$ and $\lambda=525 \mathrm{~nm}$ a mean value of $1.63 \pm 0.22$ ). This is attributed to the dominance of the organic mass within the submicron range, to which $f(\mathrm{RH})$ clearly correlates $\left(R^{2}=0.77-\right.$ 0.79). $f(\mathrm{RH})$ can thus be estimated using the continuous chemical composition measurements when no direct $f(\mathrm{RH})$ measurement is available for the aerosol found during summer months at Hyytiälä. A trajectory analysis revealed that higher values of $f(\mathrm{RH})$ and higher inorganic mass fractions at Hyytiälä were due to hygroscopic sea spray particles transported to the site.

The measurement of the $f(\mathrm{RH})$ allowed to estimate the particle light extinction coefficient at ambient RH. This was then used to extrapolate the ground-based in situ parameters to the atmospheric column using aircraft measurements of the particle number concentration as a scaling factor. The in situ derived AOD were correlated to the sun photometer measurements; however, a clear underestimation of the AOD by at least a factor of 2 was found. To investigate the reasons for this disagreement, different hypotheses were brought for-
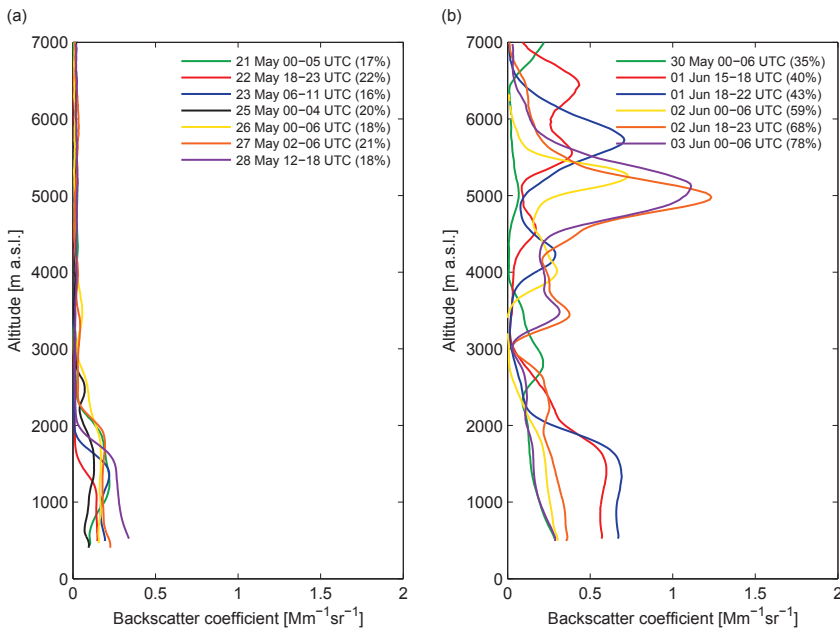

Figure 13. Aerosol backscatter coefficient profiles measured by the PollyXT lidar in Kuopio ( $200 \mathrm{~km}$ east-north-east of Hyytiälä) before (a) and during (b) the long-range transport period $(\lambda=$ $1064 \mathrm{~nm})$. The percental numbers in parentheses denote the contribution of elevated layers above $3 \mathrm{~km}$ to the total AOD of the lidar profile.

ward and discussed. An optical closure study showed the validity of the ground-based in situ measurements and showed that a lower hygroscopic growth of the organic compounds resulted in an improved agreement with respect to $f(\mathrm{RH})$. The discrepancy of the in situ derived AOD increased for larger wavelengths, pointing towards an underestimation of coarse mode particles which might have been removed by the canopy or were not sufficiently sampled by the in situ instruments. In addition, elevated layers observed by a lidar at Kuopio can explain part of the found disagreement. The remaining differences are speculated to come from dry deposition within the canopy.

This work demonstrated the difficulties faced when using ground-based in situ measurements for the validation of remote sensing (e.g. sun photometer and later even satellite) measurements. Consequently, more research work and improved measurements are needed for integrating in situ measurements for the validation or comparison of remote sensing retrievals. For sampling sites located in forest environments, the removal by the canopy of fine and coarse mode particles has to be included when analysing time series of aerosol optical properties. 
Acknowledgements. The research leading to these results has received funding from the European Union Seventh Framework Programme (FP7/2007-2013) under grant agreement no. 262254. The work was supported by US Office of Science (BER), Department of Energy via project "Biogenic Aerosols - Effects on Clouds and Climate (BAECC)", European Union (BACCHUS: 603445, PEGASOS: 265148), Nordforsk via the Nordic Center of Excellence CRAICC, the Academy of Finland via the "Center of Excellence in Atmospheric Sciences" (project no. 272041) and the European Space Agency's Climate Change Initiative (aerosol_cci; AO/1-6207/09/I-LG). We thank Janne Levula and the technical personal at Hyytiälä for their support. Ilona Riipinen is thanked for fruitful discussions. We thank the referees for their constructive and helpful comments. Paul Zieger was supported by a fellowship from the Swiss National Science Foundation (Advanced Postdoc.Mobility fellowship; grant no. P300P2_147776).

Edited by: E. Weingartner

\section{References}

Aaltonen, V., Rodriguez, E., Kazadzis, S., Arola, A., Amiridis, V., Lihavainen, H., and de Leeuw, G.: On the variation of aerosol properties over Finland based on the optical columnar measurements, Atmos. Res., 116, 46-55, doi:10.1016/j.atmosres.2011.07.014, 2012.

Allan, J., Jimenez, J., Williams, P., Alfarra, M., Bower, K., Jayne, J., Coe, H., and Worsnop, D.: Quantitative sampling using an Aerodyne aerosol mass spectrometer 1 . Techniques of data interpretation and error analysis, J. Geophys. Res., 108, 4090, doi:10.1029/2002JD002358, 2003.

Allan, J., Delia, A., Coe, H., Bower, K., Alfarra, M., Jimenez, J., Middlebrook, A., Drewnick, F., Onasch, T., Canagaratna, M., Jayne, J., and Worsnop, D.: A generalised method for the extraction of chemically resolved mass spectra from Aerodyne aerosol mass spectrometer data, J. Aerosol Sci., 35, 909-922, 2004.

Allan, J. D., Alfarra, M. R., Bower, K. N., Coe, H., Jayne, J. T., Worsnop, D. R., Aalto, P. P., Kulmala, M., Hyötyläinen, T., Cavalli, F., and Laaksonen, A.: Size and composition measurements of background aerosol and new particle growth in a Finnish forest during QUEST 2 using an Aerodyne Aerosol Mass Spectrometer, Atmos. Chem. Phys., 6, 315-327, doi:10.5194/acp-6-315-2006, 2006.

Althausen, D., Engelmann, R., Baars, H., Heese, B., Ansmann, A., Müller, D., and Komppula, M.: Portable Raman lidar PollyXT for automated profiling of aerosol backscatter, extinction, and depolarization, J. Atmos. Ocean. Tech., 26, 2366-2378, 2009.

Anderson, T., Covert, D., Marshall, S., Laucks, M., Charlson, R., Waggoner, A., Ogren, J., Caldow, R., Holm, R., Quant, F., Sem, G., Wiedensohler, A., Ahlquist, N., and Bates, T.: Performance characteristics of a high-sensitivity, three-wavelength, total scatter/backscatter nephelometer, J. Atmos. Ocean. Tech., 13, 967986, 1996.

Bohren, C. and Huffman, D.: Absorption and Scattering of Light by Small Particles, Wiley-VCH, Weinheim, Germany, 2004.

Buzorius, G., Rannik, Ü., Nilsson, E., Vesala, T., and Kulmala, M.: Analysis of measurement techniques to determine dry deposition velocities of aerosol particles with diameters less than $100 \mathrm{~nm}, \mathrm{~J}$. Aerosol Sci., 34, 747-764, 2003.

Canagaratna, M., Jayne, J., Jimenez, J., Allan, J., Alfarra, M., Zhang, Q., Onasch, T., Drewnick, F., Coe, H., Middlebrook, A., Delia, A., Williams, L., Trimborn, A., Northway, M., DeCarlo, P., Kolb, C., Davidovits, P., and Worsnop, D.: Chemical and microphysical characterization of ambient aerosols with the Aerodyne aerosol mass spectrometer, Mass Spectrom. Rev., 26, 185-222, 2007.

Carrico, C., Rood, M., and Ogren, J.: Aerosol light scattering properties at Cape Grim, Tasmania, during the first Aerosol Characterization Experiment (ACE 1), J. Geophys. Res., 103, 1656516574, doi:10.1029/98JD00685, 1998.

Carrico, C., Rood, M., Ogren, J., Neusüß, C., Wiedensohler, A., and Heintzenberg, J.: Aerosol optical properties at Sagres, Portugal, during ACE-2, Tellus B, 52, 694-715, doi:10.1034/j.16000889.2000.00049.x, 2000.

Carrico, C., Kus, P., Rood, M., Quinn, P., and Bates, T.: Mixtures of pollution, dust, sea salt, and volcanic aerosol during ACE-Asia: Radiative properties as a function of relative humidity, J. Geophys. Res., 108, 8650, doi:10.1029/2003JD003405, 2003.

Clarke, A. D., Howell, S., Quinn, P. K., Bates, T. S., Ogren, J. A., Andrews, E., Jefferson, A., Massling, A., Mayol-Bracero, O., Maring, H., Savoie, D., and Cass, G.: INDOEX aerosol: A comparison and summary of chemical, microphysical, and optical properties observed from land, ship, and aircraft, J. Geophys. Res., 107, INX2 32-1-INX2 32-32, doi:10.1029/2001JD000572, 2002.

Collins, D. R., Flagan, R. C., and Seinfeld, J. H.: Improved Inversion of Scanning DMA Data, Aerosol Sci. Technol., 36, 1-9, doi:10.1080/027868202753339032, 2002.

Covert, D. S., Charlson, R., and Ahlquist, N.: A study of the relationship of chemical composition and humidity to light scattering by aerosols, J. Appl. Meteorol., 11, 968-976, 1972.

Donahue, N., Robinson, A., Stanier, C., and Pandis, S.: Coupled partitioning, dilution, and chemical aging of semivolatile organics, Environ. Sci. Technol., 40, 2635-2643, doi:10.1021/es052297c, 2006.

Draxler, R.: Description of the HYSPLIT4 modeling system, Air Resources Laboratory, Silver Spring, Maryland, USA, NOAA Technical Memorandum ERL ARL-224 edn., 2004.

Draxler, R. R. and Hess, G.: An overview of the HYSPLIT_4 modelling system for trajectories, Aust. Met. Mag., 47, 295-308, 1998.

Dubovik, O., Sinyuk, A., Lapyonok, T., Holben, B. N., Mishchenko, M., Yang, P., Eck, T. F., Volten, H., Munoz, O., Veihelmann, B., van der Zande, W. J., Leon, J.-F., Sorokin, M., and Slutsker, I.: Application of spheroid models to account for aerosol particle nonsphericity in remote sensing of desert dust, J. Geophys. Res., 111, 1-34, doi:10.1029/2005JD006619, 2006.

Eck, T. F., Holben, B. N., Reid, J. S., Dubovik, O., Smirnov, A., O'Neill, N. T., Slutsker, I., and Kinne, S.: Wavelength dependence of the optical depth of biomass burning, urban, and desert dust aerosols, J. Geophys. Res., 104, 31333-31349, doi:10.1029/1999JD900923, 1999.

Ehn, M., Petäjä, T., Aufmhoff, H., Aalto, P., Hämeri, K., Arnold, F., Laaksonen, A., and Kulmala, M.: Hygroscopic properties of ultrafine aerosol particles in the boreal forest: diurnal variation, 
solubility and the influence of sulfuric acid, Atmos. Chem. Phys., 7, 211-222, doi:10.5194/acp-7-211-2007, 2007.

Engelmann, R., Althausen, D., Heese, B., Baars, H., and Komppula, M.: Recent upgrades of the multiwavelength polarization Raman lidar Polly XT, in: Reviewed and Revised Papers of the 26th International Laser Radar Conference, Porto Heli, Greece, 25-29 June 2012, 171-175, 2012.

Esteve, A. R., Ogren, J. A., Sheridan, P. J., Andrews, E., Holben, B. N., and Utrillas, M. P.: Sources of discrepancy between aerosol optical depth obtained from AERONET and in-situ aircraft profiles, Atmos. Chem. Phys., 12, 2987-3003, doi:10.5194/acp-122987-2012, 2012.

Ferrare, R., Melfi, S., Whiteman, D., Evans, K., and Leifer, R.: Raman lidar measurements of aerosol extinction and backscattering 1. Methods and comparisons, J. Geophys. Res., 103, 1966319672, doi:10.1029/98JD01646, 1998.

Fierz-Schmidhauser, R., Zieger, P., Wehrle, G., Jefferson, A., Ogren, J. A., Baltensperger, U., and Weingartner, E.: Measurement of relative humidity dependent light scattering of aerosols, Atmos. Meas. Tech., 3, 39-50, doi:10.5194/amt-3-392010, 2010a.

Fierz-Schmidhauser, R., Zieger, P., Gysel, M., Kammermann, L., DeCarlo, P. F., Baltensperger, U., and Weingartner, E.: Measured and predicted aerosol light scattering enhancement factors at the high alpine site Jungfraujoch, Atmos. Chem. Phys., 10, 23192333, doi:10.5194/acp-10-2319-2010, 2010 b.

Fierz-Schmidhauser, R., Zieger, P., Vaishya, A., Monahan, C., Bialek, J., O’Dowd, C. D., Jennings, S. G., Baltensperger, U., and Weingartner, E.: Light scattering enhancement factors in the marine boundary layer (Mace Head, Ireland), J. Geophys. Res., 115, D20204, doi:10.1029/2009jd013755, 2010c.

Fitzgerald, J., Hoppel, W., and Vietti, M.: The size and scattering coefficient of urban aerosol particles at Washington, DC as a function of relative humidity, J. Atmos. Sci., 39, 1838-1852, 1982.

Gasso, S., Hegg, D., Covert, D., Collins, D., Noone, K., Öström, E., Schmid, B., Russell, P., Livingston, J., Durkee, P., and Jonsson, $\mathrm{H}$.: Influence of humidity on the aerosol scattering coefficient and its effect on the upwelling radiance during ACE-2, Tellus B, 52, 546-567, 2000.

Grönholm, T., Aalto, P. P., Hiltunen, V., Rannik, Ü., Rinne, J., Laakso, L., Hyvönen, S., Vesala, T., and Kulmala, M.: Measurements of aerosol particle dry deposition velocity using the relaxed eddy accumulation technique, Tellus B, 59, 381-386, 2007.

Grönholm, T., Launiainen, S., Ahlm, L., Mårtensson, E., Kulmala, M., Vesala, T., and Nilsson, E.: Aerosol particle dry deposition to canopy and forest floor measured by two-layer eddy covariance system, J. Geophys. Res., 114, D04202, doi:10.1029/2008JD010663, 2009.

Hämeri, K., Väkevä, M., Aalto, P., Kulmala, M., Swietlicki, E., Zhou, J., Seidl, W., Becker, E., and O'Dowd, C.: Hygroscopic and $\mathrm{CCN}$ properties of aerosol particles in boreal forests, Tellus B, 53, 359-379, 2001.

Hari, P. and Kulmala, M.: Station for Measuring EcosystemAtmosphere Relations (SMEAR II), Boreal Environ. Res., 10, 315-322, 2005.

Hirsikko, A., O’Connor, E. J., Komppula, M., Korhonen, K., Pfüller, A., Giannakaki, E., Wood, C. R., Bauer-Pfundstein, M., Poikonen, A., Karppinen, T., Lonka, H., Kurri, M., Heinonen,
J., Moisseev, D., Asmi, E., Aaltonen, V., Nordbo, A., Rodriguez, E., Lihavainen, H., Laaksonen, A., Lehtinen, K. E. J., Laurila, T., Petäjä, T., Kulmala, M., and Viisanen, Y.: Observing wind, aerosol particles, cloud and precipitation: Finland's new groundbased remote-sensing network, Atmos. Meas. Tech., 7, 13511375, doi:10.5194/amt-7-1351-2014, 2014.

Holben, B., Eck, T., Slutsker, I., Tanre, D., Buis, J., Setzer, A., Vermote, E., Reagan, J., Kaufman, Y., Nakajia, T., Lavenu, F., Jankowiak, I., and Smirnov, A.: AERONET - A federated instrument network and data archive for aerosol characterization, Remote Sens. Environ., 66, 1-6, 1998.

Holben, B. N., Eck, T. F., Slutsker, I., Smirnov, A., Sinyuk, A., Schafer, J., Giles, D., and Dubovik, O.: Aeronet's Version 2.0 quality assurance criteria, Proc. SPIE 6408, P. Soc. Photo.-Opt. Ins., 64080Q doi:10.1117/12.706524, 2006.

Hong, J., Häkkinen, S. A. K., Paramonov, M., Äijälä, M., Hakala, J., Nieminen, T., Mikkilä, J., Prisle, N. L., Kulmala, M., Riipinen, I., Bilde, M., Kerminen, V.-M., and Petäjä, T.: Hygroscopicity, $\mathrm{CCN}$ and volatility properties of submicron atmospheric aerosol in a boreal forest environment during the summer of 2010, Atmos. Chem. Phys., 14, 4733-4748, doi:10.5194/acp-144733-2014, 2014.

Karanasiou, A., Diapouli, E., Cavalli, F., Eleftheriadis, K., Viana, M., Alastuey, A., Querol, X., and Reche, C.: On the quantification of atmospheric carbonate carbon by thermal/optical analysis protocols, Atmos. Meas. Tech., 4, 2409-2419, doi:10.5194/amt4-2409-2011, 2011.

Koloutsou-Vakakis, S., Carrico, C., Kus, P., Rood, M., Li, Z., Shrestha, R., Ogren, J., Chow, J., and Watson, J.: Aerosol properties at a midlatitude Northern Hemisphere continental site, J. Geophys. Res., 106, 3019-3032, 2001.

Kotchenruther, R. and Hobbs, P.: Humidification factors of aerosols from biomass burning in Brazil, J. Geophys. Res., 103, 3208132089, doi:10.1029/98JD00340, 1998.

Leino, K., Riuttanen, L., Nieminen, T., Dal Maso, M., Väänänen, R., Pohja, T., Keronen, P., Järvi, L., Aalto, P. P., Virkkula, A., Kerminen, V.-M., Petäjä, T., and Kulmala, M.: Biomass-burning smoke episodes in Finland from eastern European wildfires, Boreal Env. Res., 19 (suppl. B), 275-292, 2014.

McInnes, L., Bergin, M., Ogren, J., and Schwartz, S.: Apportionment of light scattering and hygroscopic growth to aerosol composition, Geophys. Res. Lett., 25, 513-516, doi:10.1029/98GL00127, 1998.

McNaughton, C., Clarke, A., Howell, S., Pinkerton, M., Anderson, B., Thornhill, L., Hudgins, C., Winstead, E., Dibb, J., Scheuer, E., and Maring, H.: Results from the DC-8 Inlet Characterization Experiment (DICE): Airborne versus surface sampling of mineral dust and sea salt aerosols, Aerosol Sci. Technol., 41, 136159, doi:10.1080/02786820601118406, 2007.

Morgan, W. T., Allan, J. D., Bower, K. N., Esselborn, M., Harris, B., Henzing, J. S., Highwood, E. J., Kiendler-Scharr, A., McMeeking, G. R., Mensah, A. A., Northway, M. J., Osborne, S., Williams, P. I., Krejci, R., and Coe, H.: Enhancement of the aerosol direct radiative effect by semi-volatile aerosol components: airborne measurements in North-Western Europe, Atmos. Chem. Phys., 10, 8151-8171, doi:10.5194/acp-10-81512010, 2010.

Müller, T., Laborde, M., Kassell, G., and Wiedensohler, A.: Design and performance of a three-wavelength LED-based total scatter 
and backscatter integrating nephelometer, Atmos. Meas. Tech., 4, 1291-1303, doi:10.5194/amt-4-1291-2011, 2011.

Nessler, R., Weingartner, E., and Baltensperger, U.: Effect of humidity on aerosol light absorption and its implications for extinction and the single scattering albedo illustrated for a site in the lower free troposphere, J. Aerosol Sci., 36, 958-972, doi:10.1016/j.jaerosci.2004.11.012, 2005.

Ng, N., Herndon, S., Trimborn, A., Canagaratna, M., Croteau, P., Onasch, T., Sueper, D., Worsnop, D., Zhang, Q., Sun, Y., and Jayne, J.: An Aerosol Chemical Speciation Monitor (ACSM) for routine monitoring of the composition and mass concentrations of ambient aerosol, Aerosol Sci. Technol., 45, 780-794, 2011.

Pan, X. L., Yan, P., Tang, J., Ma, J. Z., Wang, Z. F., Gbaguidi, A., and Sun, Y. L.: Observational study of influence of aerosol hygroscopic growth on scattering coefficient over rural area near Beijing mega-city, Atmos. Chem. Phys., 9, 7519-7530, doi:10.5194/acp-9-7519-2009, 2009.

Pappalardo, G., Amodeo, A., Apituley, A., Comeron, A., Freudenthaler, V., Linné, H., Ansmann, A., Bösenberg, J., D’Amico, G., Mattis, I., Mona, L., Wandinger, U., Amiridis, V., AladosArboledas, L., Nicolae, D., and Wiegner, M.: EARLINET: towards an advanced sustainable European aerosol lidar network, Atmos. Meas. Tech., 7, 2389-2409, doi:10.5194/amt-7-23892014, 2014.

Petäjä, T., Kerminen, V.-M., Hämeri, K., Vaattovaara, P., Joutsensaari, J., Junkermann, W., Laaksonen, A., and Kulmala, M.: Effects of $\mathrm{SO}_{2}$ oxidation on ambient aerosol growth in water and ethanol vapours, Atmos. Chem. Phys., 5, 767-779, doi:10.5194/acp-5-767-2005, 2005.

Peterson, M. R. and Richards, M. H.: Thermal-opticaltransmittance analysis for organic, elemental, carbonate, total carbon, and OCX2 in $\mathrm{PM}_{2.5}$ by the EPA/NIOSH method, in: Proceedings, Symposium on Air Quality Measurement Methods and Technology-2002, edited by: Winegar, E. D. and Tropp, R. J., Air \& Waste Management Association, Pittsburgh, PA, 83-1-83-19, 2002.

Petroff, A., Mailliat, A., Amielh, M., and Anselmet, F.: Aerosol dry deposition on vegetative canopies. Part I: Review of present knowledge, Atmos. Environ., 42, 3625-3653, 2008.

Petzold, A., Ogren, J. A., Fiebig, M., Laj, P., Li, S.-M., Baltensperger, U., Holzer-Popp, T., Kinne, S., Pappalardo, G., Sugimoto, N., Wehrli, C., Wiedensohler, A., and Zhang, X.-Y.: Recommendations for reporting "black carbon" measurements, Atmos. Chem. Phys., 13, 8365-8379, doi:10.5194/acp-13-83652013, 2013.

Pilat, M. and Charlson, R.: Theoretical and optical studies of humidity effects on the size distribution of a hygroscopic aerosol, J. Rech. Atmos., 2, 166-170, 1966.

Pilinis, C., Pandis, S., and Seinfeld, J.: Sensitivity of direct climate forcing by atmospheric aerosols to aerosol size and composition, J. Geophys. Res., 100, 18739-18754, doi:10.1029/95JD02119, 1995.

Quinn, P., Bates, T., Baynard, T., Clarke, A., Onasch, T., Wang, W., Rood, M., Andrews, E., Allan, J., Carrico, C., Coffman, D., and Worsnop, D.: Impact of particulate organic matter on the relative humidity dependence of light scattering: A simplified parameterization, Geophys. Res. Lett., 32, L22809, doi:10.1029/2005GL024322, 2005.
Riipinen, I., Rastak, N., and Pandis, S. N.: Connecting the solubility and CCN activation of complex organic aerosols: a theoretical study using solubility distributions, Atmos. Chem. Phys., 15, 6305-6322, doi:10.5194/acp-15-6305-2015, 2015.

Schobesberger, S., Väänänen, R., Leino, K., Virkkula, A., Backman, J., Pohja, T., Siivola, E., Franchin, A., Mikkilä, J., Paramonov, M., Aalto, P., Krejci, R., Petäjä, T., and Kulmala, M.: Airborne measurements over the boreal forest of southern Finland during new particle formation events in 2009 and 2010, Boreal Env. Res., 18, 145-163, 2013.

Sheridan, P., Delene, D., and Ogren, J.: Four years of continuous surface aerosol measurements from the Department of Energy's Atmospheric Radiation measurement Program Southern Great Plains Cloud and Radiation Testbed site, J. Geophys. Res., 106, 20735-20747, 2001.

Swietlicki, E., Hansson, H., Hämeri, K., Svenningsson, B., Massling, A., McFiggans, G., McMurry, P., Petäjä, T., Tunved, P., Gysel, M., Topping, D., Weingartner, E., Baltensperger, U., Rissler, J., Wiedensohler, A., and Kulmala, M.: Hygroscopic properties of submicrometer atmospheric aerosol particles measured with H-TDMA instruments in various environments - a review, Tellus B, 60, 432-469, 2008.

Tesche, M., Zieger, P., Rastak, N., Charlson, R. J., Glantz, P., Tunved, P., and Hansson, H.-C.: Reconciling aerosol light extinction measurements from spaceborne lidar observations and in situ measurements in the Arctic, Atmos. Chem. Phys., 14, 78697882, doi:10.5194/acp-14-7869-2014, 2014.

Titos, G., Jefferson, A., Sheridan, P. J., Andrews, E., Lyamani, H., Alados-Arboledas, L., and Ogren, J. A.: Aerosol light-scattering enhancement due to water uptake during the TCAP campaign, Atmos. Chem. Phys., 14, 7031-7043, doi:10.5194/acp-14-70312014, 2014a.

Titos, G., Lyamani, H., Cazorla, A., Sorribas, M., Foyo-Moreno, I., Wiedensohler, A., and Alados-Arboledas, L.: Study of the relative humidity dependence of aerosol light-scattering in southern Spain, Tellus B, 66, 24536, doi:10.3402/tellusb.v66.24536, 2014b.

Toon, O., Pollack, J., and Khare, B.: The optical constants of several atmospheric aerosol species: Ammonium sulfate, aluminum oxide, and sodium chloride, J. Geophys. Res., 81, 5733-5748, doi:10.1029/JC081i033p05733, 1976.

Väänänen, R., Krejci, R., Manninen, H., Nieminen, T., Yli-Juuti, T., Kangasluoma, J., Pohja, T., Aalto, P., Petäjä, T., and Kulmala, M.: Aircraft-borne measurements over southern Finland during Pegasos spring 2013 campaign, in preparation, 2015.

Vesala, T., Haataja, J., Aalto, P., Altimir, N., Buzorius, G., Garam, E., Hämeri, K., Ilvesniemi, H., Jokinen, V., Keronen, P., Lahti, T., Markkanen, T., Mäkelä, J., E., N., Palmmroth, S., Palva, L., Pohja, T., Pumpanen, J., Rannik, U., Siivola, E., Ylitalo, H., Hari, P., and Kulmala, M.: Long-term field measurements of atmospheresurface interaction in boreal forest combining forest ecology, micrometeorology, aerosol physics and atmospheric chemistry, Trends in Heat, Mass \& Mommentum Transfer, 4, 17-35, 1998.

Virkkula, A., Backman, J., Aalto, P. P., Hulkkonen, M., Riuttanen, L., Nieminen, T., dal Maso, M., Sogacheva, L., de Leeuw, G., and Kulmala, M.: Seasonal cycle, size dependencies, and source analyses of aerosol optical properties at the SMEAR II measurement station in Hyytiälä, Finland, Atmos. Chem. Phys., 11, 4445-4468, doi:10.5194/acp-11-4445-2011, 2011. 
Voss, K., Welton, E., Quinn, P., Frouin, R., Miller, M., and Reynolds, R.: Aerosol optical depth measurements during the Aerosols99 experiment, J. Geophys. Res., 106, 20821-20831, doi:10.1029/2000JD900783, 2001.

Wang, S. and Flagan, R.: Scanning Electrical Mobility Spectrometer, Aerosol Sci. Technol., 13, 230-240, doi:10.1080/02786829008959441, 1990.

Wang, W., Rood, M., Carrico, C., Covert, D., Quinn, P., and Bates, T.: Aerosol optical properties along the northeast coast of North America during the New England Air Quality StudyIntercontinental Transport and Chemical Transformation 2004 campaign and the influence of aerosol composition, J. Geophys. Res., 112, D10S23, doi:10.1029/2006JD007579, 2007.

Weingartner, E., Saathoff, H., Schnaiter, M., Streit, N., Bitnar, B., and Baltensperger, U.: Absorption of light by soot particles: Determination of the absorption coefficient by means of Aethalometers, J. Aerosol Sci., 34, 1445-1465, 2003.

Wiedensohler, A., Birmili, W., Nowak, A., Sonntag, A., Weinhold, K., Merkel, M., Wehner, B., Tuch, T., Pfeifer, S., Fiebig, M., Fjäraa, A. M., Asmi, E., Sellegri, K., Depuy, R., Venzac, H., Villani, P., Laj, P., Aalto, P., Ogren, J. A., Swietlicki, E., Williams, P., Roldin, P., Quincey, P., Hüglin, C., Fierz-Schmidhauser, R., Gysel, M., Weingartner, E., Riccobono, F., Santos, S., Grüning, C., Faloon, K., Beddows, D., Harrison, R., Monahan, C., Jennings, S. G., O’Dowd, C. D., Marinoni, A., Horn, H.-G., Keck, L., Jiang, J., Scheckman, J., McMurry, P. H., Deng, Z., Zhao, C. S., Moerman, M., Henzing, B., de Leeuw, G., Löschau, G., and Bastian, S.: Mobility particle size spectrometers: harmonization of technical standards and data structure to facilitate high quality long-term observations of atmospheric particle number size distributions, Atmos. Meas. Tech., 5, 657-685, doi:10.5194/amt5-657-2012, 2012.

WMO/GAW: Aerosol Measurement Procedures Guidelines and Recommendations, Report No. 153, World Meteorological Organization, Geneva, Switzerland, 2003.

Yan, P., Pan, X., Tang, J., Zhou, X., Zhang, R., and Zeng, L.: Hygroscopic growth of aerosol scattering coefficient: A comparative analysis between urban and suburban sites at winter in Beijing, Particuology, 7, 52-60, 2009.
York, D., Evensen, N., Martínez, M., and Delgado, J.: Unified equations for the slope, intercept, and standard errors of the best straight line, Am. J. Phys., 72, 367-375, doi:10.1119/1.1632486, 2004.

Zhang, L., Sun, J. Y., Shen, X. J., Zhang, Y. M., Che, H. C., Ma, Q. L., Zhang, Y. W., Zhang, X. Y., and Ogren, J. A.: Observations of relative humidity effects on aerosol light scattering in the Yangtze River Delta of China, Atmos. Chem. Phys. Discuss., 15, 2853-2904, doi:10.5194/acpd-15-2853-2015, 2015.

Zieger, P., Fierz-Schmidhauser, R., Gysel, M., Ström, J., Henne, S., Yttri, K. E., Baltensperger, U., and Weingartner, E.: Effects of relative humidity on aerosol light scattering in the Arctic, Atmos. Chem. Phys., 10, 3875-3890, doi:10.5194/acp-10-38752010, 2010.

Zieger, P., Weingartner, E., Henzing, J., Moerman, M., de Leeuw, G., Mikkilä, J., Ehn, M., Petäjä, T., Clémer, K., van Roozendael, M., Yilmaz, S., Frieß, U., Irie, H., Wagner, T., Shaiganfar, R., Beirle, S., Apituley, A., Wilson, K., and Baltensperger, U.: Comparison of ambient aerosol extinction coefficients obtained from in-situ, MAX-DOAS and LIDAR measurements at Cabauw, Atmos. Chem. Phys., 11, 2603-2624, doi:10.5194/acp11-2603-2011, 2011.

Zieger, P., Kienast-Sjögren, E., Starace, M., von Bismarck, J., Bukowiecki, N., Baltensperger, U., Wienhold, F. G., Peter, T., Ruhtz, T., Collaud Coen, M., Vuilleumier, L., Maier, O., Emili, E., Popp, C., and Weingartner, E.: Spatial variation of aerosol optical properties around the high-alpine site Jungfraujoch (3580 m a.s.1.), Atmos. Chem. Phys., 12, 72317249, doi:10.5194/acp-12-7231-2012, 2012.

Zieger, P., Fierz-Schmidhauser, R., Weingartner, E., and Baltensperger, U.: Effects of relative humidity on aerosol light scattering: results from different European sites, Atmos. Chem. Phys., 13, 10609-10631, doi:10.5194/acp-13-10609-2013, 2013.

Zieger, P., Fierz-Schmidhauser, R., Poulain, L., Müller, T., Birmili, W., Spindler, G., Wiedensohler, A., Baltensperger, U., and Weingartner, E.: Influence of water uptake on the aerosol particle light scattering coeffcients of the Central European aerosol, Tellus B, 66, 22716, doi:10.3402/tellusb.v66.22716, 2014. 